\title{
Chemistry of Diamino-Ligated Methylpalladium(II) Alkoxide Complexes: Syntheses, X-ray Crystal Structures, and Hydrogen-Bond Formation
}

\author{
Gerardus M. Kapteijn, ${ }^{\dagger}$ Athanasia Dervisi, ${ }^{\dagger}$ David M. Grove, ${ }^{\dagger}$ Huub Kooijman, ${ }^{\ddagger}$ \\ Miles T. Lakin, ${ }^{\ddagger}$ Anthony L. Spek, ${ }^{\ddagger}, 8$ and Gerard van Koten ${ }^{*, \dagger}$
}

Contribution from the Department of Metal-Mediated Synthesis, Debye Institute, and Crystal and Structural Chemistry, Bijvoet Center for Biomolecular Research, Utrecht University, Padualaan 8, $3584 \mathrm{CH}$ Utrecht, The Netherlands

Received March 16, $1995^{8}$

\begin{abstract}
The reaction of diamino-ligated dimethylpalladium(II) complexes $\left[\mathrm{Pd}(\mathrm{Me})_{2}(\mathrm{~N} \sim \mathrm{N})\right](\mathrm{N} \sim \mathrm{N}=$ tmeda, bpy) with an equimolar amount of 1,1,1,3,3,3-hexafluoro-2-propanol or (substituted) phenols affords the new complexes $[\mathrm{Pd}(\mathrm{Me})(\mathrm{OR})(\mathrm{N} \sim \mathrm{N})]\left(\mathrm{N} \sim \mathrm{N}=\right.$ tmeda, $\left.\mathrm{R}=\mathrm{CH}\left(\mathrm{CF}_{3}\right)_{2}(\mathbf{1}), \mathrm{C}_{6} \mathrm{H}_{5}(3), \mathrm{C}_{6} \mathrm{H}_{4}-4-\mathrm{NO}_{2}(4), \mathrm{C}_{6} \mathrm{H}_{4}-2-\mathrm{OH}(\mathbf{1 1})\right) ; \mathrm{N} \sim \mathrm{N}=$ bpy, $\left.\mathrm{R}=\mathrm{CH}\left(\mathrm{CF}_{3}\right)_{2}(2)\right)$. These methylpalladium(II) alkoxides and aryloxides are isolated in high yields as yelloworange solids and are remarkably thermally stable. Mono- or bidentate ligands can substitute the tmeda ligand in 1 to afford a variety of methylpalladium alkoxide complexes $\left[\mathrm{Pd}(\mathrm{Me})\left(\mathrm{OCH}\left(\mathrm{CF}_{3}\right)_{2}\right) \mathrm{L}_{2}\right]\left(\mathrm{L}_{2}=\right.$ bpy $(2), \mathrm{Ph}_{2} \mathrm{PCH}_{2} \mathrm{CH}_{2}-$ $\mathrm{NMe}_{2}(12)$, dppe (13), 2PMe 3 (14)). Crystals of 1, 3, and 4 have been subjected to X-ray diffraction studies. Crystals of 1 are monoclinic, space group $P 2{ }_{1} / c$, with unit-cell dimensions $a=8.2054(5) \AA, b=17.2310(9) \AA, c=11.1191$ (12) $\AA, \beta=105.701(7)^{\circ}$, and $Z=4$. Crystals of 3 are orthorhombic, space group $P b c a$, with unit-cell dimensions $a=10.572(2) \AA, b=16.446(2) \AA, c=17.029(3) \AA$, and $Z=8$. Crystals of 4 are orthorhombic, space group $P b c a$, with unit-cell dimensions $a=11.918(5) \AA, b=12.089(3) \AA, c=22.684(7) \AA$, and $Z=8$. The molecular structures of these complexes show them to be square-planar species, and in 1 the $C_{\beta}-\mathrm{H}$ unit of the fluorinated alkoxide is directed toward the palladium center $(\mathrm{H} \cdot \cdot \mathrm{Pd}=2.89(3) \AA)$, in what can be interpreted as the incipient stage of a $\beta$-hydrogen elimination. The palladium alkoxide or aryloxide complexes 1-4 when treated with 1 equiv of the corresponding alcohol or (substituted) phenol afford $\mathrm{O}-\mathrm{H} \cdots \mathrm{O}$ hydrogen-bonded adducts $[\mathrm{Pd}(\mathrm{Me})(\mathrm{OR})(\mathrm{N} \sim \mathrm{N})] \cdot-$ HOR $\left(\mathrm{N} \sim \mathrm{N}=\right.$ tmeda, $\mathrm{R}=\mathrm{CH}\left(\mathrm{CF}_{3}\right)_{2}(\mathbf{5}), \mathrm{C}_{6} \mathrm{H}_{5}(7), \mathrm{C}_{6} \mathrm{H}_{4}-4-\mathrm{NO}_{2}(\mathbf{8}) ; \mathrm{N} \sim \mathrm{N}=$ bpy, $\left.\mathrm{R}=\mathrm{CH}\left(\mathrm{CF}_{3}\right)_{2}(6), \mathrm{C}_{6} \mathrm{H}_{5}(\mathbf{9})\right)$. The X-ray molecular structures of $\left[\mathrm{Pd}(\mathrm{Me})\left(\mathrm{OC}_{6} \mathrm{H}_{5}\right)(\mathrm{tmeda})\right] \cdot \mathrm{HOC}_{6} \mathrm{H}_{5}(7)$ and $\left[\mathrm{Pd}(\mathrm{Me})\left(\mathrm{OC}_{6} \mathrm{H}_{4}-4-\mathrm{NO}_{2}\right)(\mathrm{tmeda})\right] \cdot-$ $\mathrm{HOC}_{6} \mathrm{H}_{4}-4-\mathrm{NO}_{2}(8)$ reveal that the aromatic alcohol is associated with the oxygen atom of the aryloxide through $\mathrm{O}-\mathrm{H} \cdots \mathrm{O}$ hydrogen bonding. Crystals of 7 are monoclinic, space group $P 2_{1} / c$, with unit-cell dimensions $a=15.5556-$ (13) $\AA, b=11.0416(10) \AA, c=12.0211(11) \AA, \beta=91.343(8)^{\circ}$, and $Z=4$. Crystals of 8 are monoclinic, space group $P 2_{1} / c$, with unit-cell dimensions $a=8.7029(5) \AA, b=15.6384(11) \AA, c=16.5188(9) \AA, \beta=90.096(5)^{\circ}$, and $Z=4$. Comparison of the solid state structures of $\left[\mathrm{Pd}(\mathrm{Me})\left(\mathrm{OC}_{6} \mathrm{H}_{4}-4-\mathrm{NO}_{2}\right)(\mathrm{tmeda})\right](4)$ and its $\mathrm{HOC}_{6} \mathrm{H}_{4}-4-\mathrm{NO}_{2}$ adduct (8) reveal that an electron-withdrawing substituent on the aryloxide ring leads to geometric changes in the $\mathrm{Pd}-\mathrm{O}-\mathrm{C}$ unit. Proton NMR for 5-9 and the X-ray structural data of 7 and 8 indicate that the $\mathrm{O}-\mathrm{H} \cdots \mathrm{O}$ hydrogen bonding in these adducts is strong both in solution and in the solid state. The thermodynamic parameters for the alkoxide-alcohol exchange in the adduct $\left[\mathrm{Pd}(\mathrm{Me})\left(\mathrm{OCH}\left(\mathrm{CF}_{3}\right)_{2}\right)(\mathrm{tmeda})\right] \cdot \mathrm{HOCH}\left(\mathrm{CF}_{3}\right)_{2}(5)$ have been determined with NMR spin saturation transfer techniques and provide evidence for a five-coordinate species being the key intermediate in this intramolecular exchange reaction. Furthermore, the thermodynamic parameters for adduct formation, obtained by the Scatchard method, quantify the $\mathrm{O}-\mathrm{H} \cdots \mathrm{O}$ hydrogen bond as being strong.
\end{abstract}

\section{Introduction}

Recently, the chemistry of late transition metal alkoxide complexes has attracted much attention. ${ }^{1-9}$ One reason for this

\footnotetext{
* To whom correspondence should be addressed.

+ Debye Institute, Utrecht University.

₹ Bijvoet Center for Biomolecular Research, Utrecht University.

$\S$ Address correspondence pertaining to crystallographic studies to this author.

${ }^{\otimes}$ Abstract published in Advance ACS Abstracts, October 15, 1995.

(1) For reviews concerning transition metal alkoxides, see: (a) Mehrotra, R. C.; Agarwal, S. K.; Singh, Y. P. Coord. Chem. Rev. 1985, 68, 101. (b) Willis, C. J. Coord. Chem. Rev. 1988, 88, 133. (c) Bryndza, H. E.; Tam, W. Chem. Rev, 1988, 88, 1163.

(2) (a) Tsuji, J.; Minami, I. Acc. Chem. Res. 1987, 20, 140. (b) Venanzi, L. M.; Gorla, F. Helv. Chim. Acta 1990, 73, 690. (c) Alper, H.; Ali, B. J. Mol. Catal. 1991, 67, 29. (d) Barbaro, P.; Bianchini, C.; Frediani, P.; Meli, A.; Vizza, F. Inorg. Chem. 1992, 31, 1523. (e) Sen, A.; Lin, M.; Kao, L.-C.; Hutson, A. C. J. Am. Chem. Soc. 1992, 114, 6385. (f) Carpentier J. F.; Castanet, Y.; Mortreux, A.; Petit, F. J. Organomet. Chem. 1994, 482, 31 .
}

is that such complexes have been postulated as key intermediates in various transition metal-catalyzed processes. ${ }^{2}$ Recent examples of (alkoxo)palladium-catalyzed processes include not only the perfectly alternating copolymerization of $\mathrm{CO}$ and olefins to produce polyketones, ${ }^{3}$ but also the methoxycarbonylation of propyne to give methyl methacrylate. ${ }^{4}$ An earlier belief that the metal-to-oxygen bond is weak, as a result of the occurrence of antibonding $\pi$-interactions between filled metal

(3) Drent, E.; Broekhoven van, J. A. M.; Doyle, M. J. Organometallics $1990,417,235$.

(4) (a) Drent, E.; Arnoldy, P.; Budzelaar, P. H. M. Organometallics 1993, 455, 247. (b) Drent, E.; Amoldy, P.; Budzelaar, P. H. M. J. Organomet. Chem. 1994, 475, 57.

(5) (a) Mayer, J. M. Comments Inorg. Chem. 1988, 8, 125. (b) Evidence has been obtained for alkoxide $\pi$-donation to an $\operatorname{Ir}($ III) center: Lunder, $D$. M.; Lobkovsky, E. B.; Streib, W. E.; Caulton, K. G. J. Am. Chem. Soc. 1991, 113, 1837.

(6) (a) Bäckvall, J. E.; Bjorkman, E. E.; Petterson, L.; Siegbahn, R. J. J. Am. Chem. Soc. 1984, 106, 4369. (b) Bäckvall, J. E.; Bjorkman, E. E.; Petterson, L.; Siegbahn, R. J. J. Am. Chem. Soc. 1985, 107, 7265. 
d-orbitals and oxygen lone pairs, ${ }^{5}$ may have limited research in this area, and reports concerning late transition metal alkoxides and aryloxides are still rare, in particular when the other ligands are mono- or bidentate tertiary amines. It is now recognized, however, that the metal-to-oxygen bond may be of comparable strength or even stronger than the metal-to-carbon$\left(\mathrm{sp}^{3}\right)$ bond. ${ }^{6}$

Reported interesting properties of late transition metal alkoxides include $\mathrm{C}-\mathrm{O}$ bond formation, ${ }^{7}$ insertion of small molecules into the metal-to-oxygen bond,$^{8}$ and $\beta$-hydrogen elimination from the alkoxide ligand to release aldehydes or ketones. ${ }^{9}$ Another intriguing feature of late transition metal alkoxides is their ability to associate with alcohols, and so form adducts, through $\mathrm{O}-\mathrm{H} \cdots \mathrm{O}$ hydrogen bonding (eq 1 ). ${ }^{10}$

$$
L_{n} M-O_{R}+H O R \stackrel{k_{\text {ass }}}{=} L_{n} M-O^{\prime} \cdot{ }^{\prime} H^{-O-R}
$$

The nature of the $\mathrm{O}-\mathrm{H} \cdots \mathrm{O}$ hydrogen bond has been studied in great detail in organic chemistry. ${ }^{11}$ Now, studies of organometallic and inorganic complexes are showing that $\mathrm{O}-\mathrm{H} \cdots \mathrm{O}$ hydrogen bonding can be an important factor in this field of chemistry as well. ${ }^{12}$ In transition metal alkoxide chemistry the isolation of alcohol adducts shows the existence of a strong tendency for the formation of $\mathrm{O}-\mathrm{H} \cdots \mathrm{O}$ hydrogen bonds. ${ }^{10}$ Extreme examples of this tendency are reactions in which an

(7) (a) Bernard, K. A.; Churchill, M. R.; Janik, T. S.; Atwood, J. D. Organometallics 1990, 9, 12. (b) Thompson, J. S.; Bernard, K. A.; Rappoli, B. J.; Atwood, J. D. Organometallics 1990, 9, 2727 . (c) Glueck, D. S.; Newman Winslow, L. J.; Bergman, R. G. Organometallics 1991, 10, 1462. (d) Thompson, J. S.; Randall, S. L.; Atwood, J. D. Organometallics 1991, 10, 3906. (e) Alsters, P. L.; Boersma, J.; van Koten, G. Tetrahedron Lett. 1991, 32, 675. (f) Alsters, P. L.; Boersma, J.; Smeets, W. J. J.; Spek, A. L.; van Koten, G. Organometallics 1993, 12, 1639. (g) Hoffman, D. M.; Lappas, D.; Wierda, D. A. J. Am. Chem. Soc. 1993, 115, 10538.

(8) (a) Kim, Y.-J.; Osakada, K.; Sugita, K.; Yamamoto, T.; Yamamoto, A. Organometallics 1988, 7, 2182. (b) Hartwig, J. F.; Bergman, R. G.: Andersen, R. A. J. Am. Chem. Soc. 1991, 113, 6499. (c) Simpson, R. D.; Bergman, R. D. Organometallics 1992, 11,4306 . (d) Mandal, S. K.; Ho, D. M.; Orchin, M. Organometallics 1993, 12, 1714. (e) Tsuji, J.; Mandai, T. J. Organomet. Chem. 1993, 451, 15 . (f) Smith, J. D.; Hansson, B. E.; Merola, J. S.; Waller, F. J. Organometallics 1993, 12, 568. (g) Tóth, I.; Elsevier, C. J. J. Chem. Soc., Chem. Commun. 1993, 529. (h) Bertani, R.; Cavinato, G.; Tonioli, L.; Vasapollo, G. J. Mol. Catal. 1993, 84, 165. (i) Vasapollo, G.; Tonioli, L.; Cavinato, G.; Bigoli, F.; Lanfranchi, M.; Pellinghelli, M. A. J. Organomet. Chem. 1994, 481, 173. (j) Elsevier, C. J. J. Mol. Catal. 1994, 92, 285.

(9) (a) Bernard, K. A.: Rees, W. M.; Atwood, J. D. Organometallics 1986, 5, 390. (b) Bryndza, H. E.; Calabrese, J. C.; Marsi, M.; Roe, D. C.; Tam, W.; Bercaw, J. E. J. Am. Chem. Soc. 1986, 108, 4805. (c) Goldman, A. S.; Halpern, J. J. Am. Chem. Soc. 1987, 109, 7537. (d) Hoffman, D. M.; Lappas, D.; Wierda, D. A. J. Am. Chem. Soc, 1993, 115, 10538. (e) Blum, O.; Milstein, D. Angew. Chem., Int. Ed. Engl. 1995, 34, 229.

(10) (a) Kim, Y.-J.: Osakada, K.: Takenaka, A.; Yamamoto, A. J. Am. Chem. Soc. 1990, 112, 1096. (b) Kegley, S. E.; Schaverien, C. J.; Freudenberger, J. H.; Bergman, R, G.; Nolan, S. P.; Hoff, C. D. J. Am. Chem. Soc. 1987, 109, 6563. (c) Kim. Y.-J.; Osakada, K.; Yamamoto, A. Bull. Chem. Soc. Jpn. 1989, 62, 964. (d) Osakada, K.; Oshiro, K.; Yamamoto, A. Organometallics 1991, 10, 404. (e) Di Bugno, C.; Pasquali, M.: Leoni, P.: Sabatino, P.: Braga, D. Inorg. Chem. 1989, 28, 1390. (f) Osakada, K.; Kim, K.-Y.; Yamamoto, A. J. Organomet. Chem. 1990, 382 , 303. (g) Seligson, A. L.; Cowan, R. L.; Trogler, W. C. Inorg. Chem. 1991 30, 3371. (h) Simpson, R. D.; Bergman, R. G. Organometallics 1993, 12, 781. (i) Seligson, A. L.; Cowan, R. L.; Trogler, W. C. Inorg. Chem. 1991 30, 1096. (j) Ozawa, F.; Yamagami, I.; Yamamoto, A. J. Organomet. Chem. 1994, 473, 265. (k) Osakada, K.; Kim, Y.-J.; Tanaka, M.; Ishiguro, S.-I.; Yamamoto, A. Inorg. Chem. 1991, 30, 197.

(11) (a) Schuster, P.; Zundel, G.; Sandorfy, C. The Hydrogen Bond; North-Holland: Amsterdam, 1976. (b) Joesten, M. D.; Schaad, L. J. Hydrogen Bonding: Marcel Dekker: New York, 1974. (c) Pimentel, G. C.; McLellan, A. L. The Hydrogen Bond; W. H. Freeman: San Francisco, $\mathrm{CA}, 1960$. For more recent studies concerning hydrogen bonds see: (d) Scheiner, S. Acc. Chem. Res. 1994, 27, 402. (e) Gille, P.; Bertolasi, V. Ferritti, V.; Gilli, G. J. Am. Chem. Soc. 1994, 116, 909

(12) Braga, D.; Grepioni, F.; Sabatino, P.; Desiraju, G. R. Organometallics 1994, 13, 3532 and references cited therein. additional amount of alcohol (accounting for $\mathrm{O}-\mathrm{H} \cdots \mathrm{O}$ hydrogen bonding) is actually needed to drive the metal alkoxide formation to completion. ${ }^{10, \mathrm{~h}}$

When the organic group $\mathrm{R}$ of an alcohol, $\mathrm{ROH}$, is an electronwithdrawing unit, the assocation equilibrium (eq 1) is shifted to the right (adduct formation) as a result of the formation of a stronger $\mathrm{O}-\mathrm{H} \cdots \mathrm{O}$ hydrogen bond. We have shown that the presence of a strong trans-positioned $\sigma$-donor is not a prerequisite for the formation of strong $\mathrm{O}-\mathrm{H} \cdots \mathrm{O}$ hydrogen bonding (in terms of $\Delta H^{\circ}$ ) and that the strength of the $\mathrm{O}-\mathrm{H} \cdots \mathrm{O}$ hydrogen bond for transition metal alkoxides is determined by other factors as well. ${ }^{13}$ Because the $\mathrm{O}-\mathrm{H} \cdots \mathrm{O}$ hydrogen bond in transition metal alkoxide chemistry also persists to a large extent in solution, ${ }^{10,13}$ detailed thermodynamic studies of this interaction using NMR spectroscopy ${ }^{10 a, 13}$ or calorimetry ${ }^{10 b, 13}$ are possible and have shown that this type of $\mathrm{O}-\mathrm{H} \cdots \mathrm{O}$ hydrogen bond is fairly strong.

In the course of our study of N-ligated (aryloxo)palladium(II) complexes of the type $\left[\mathrm{Pd}(\mathrm{OR})_{2} \mathrm{~L}_{2}\right],{ }^{14}$ we have also observed $\mathrm{O}-\mathrm{H} \cdots \mathrm{O}$ hydrogen-bond formation with aryl alcohols. The molecular structure of the "mixed" alkoxo(aryloxo)palladium(II) adduct $\left[\mathrm{Pd}\left(\mathrm{OCH}\left(\mathrm{CF}_{3}\right)_{2}\right)\left(\mathrm{OC}_{6} \mathrm{H}_{5}\right)(\mathrm{bpy})\right] \cdot \mathrm{HOC}_{6} \mathrm{H}_{5}$ shows the presence not only of an intermolecular $\mathrm{O}-\mathrm{H} \cdots \mathrm{O}$ hydrogen bond but also of an intramolecular $\mathrm{C}-\mathrm{H} \cdots \mathrm{O}$ interaction. ${ }^{\text {14a }}$ We report here full details of our study on the synthesis, characterization, and properties of $\mathrm{N}$-ligated methylpalladium(II) alkoxides or aryloxides of the type $[\mathrm{Pd}(\mathrm{Me})(\mathrm{OR})(\mathrm{N} \sim \mathrm{N})]$ and the adducts they form with alcohols. Thermodynamic data have been determined for the $\mathrm{O}-\mathrm{H} \cdots \mathrm{O}$ bond interaction in the latter complexes, and the role and importance of this interaction are discussed.

\section{Results and Discussion}

Preparation of Methylpalladium Alkoxide and Aryloxide Species and Their Adducts. The 1:1 molar reaction of dimethylpalladium(II) complexes containing bidentate nitrogen donor ligands, i.e., $\left[\mathrm{Pd}(\mathrm{Me})_{2}(\mathrm{~N} \sim \mathrm{N})\right](\mathrm{N} \sim \mathrm{N}=$ tmeda, bpy), with organic compounds $\mathrm{ROH}$ has been used to prepare the new methylpalladium(II) alkoxide and aryloxide complexes $[\mathrm{Pd}(\mathrm{Me})$ $(\mathrm{OR})(\mathrm{N} \sim \mathrm{N})](\mathbf{1}-\mathbf{4})$ as shown in eq 2 . This reaction, in which

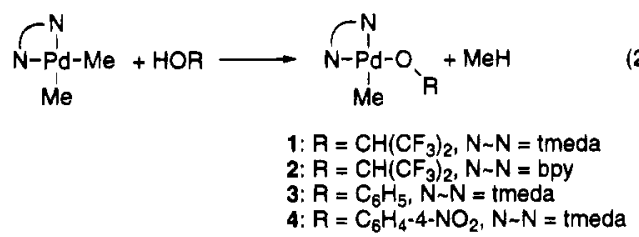

$\mathrm{CH}_{4}$ is the byproduct, has proved successful for $1,1,1,3,3,3-$ hexafluoro-2-propanol $\left(\mathrm{p} K_{\mathrm{a}}=9.3\right)$ and the phenols $\mathrm{C}_{6} \mathrm{H}_{5} \mathrm{OH}$ $\left(\mathrm{p} K_{\mathrm{a}}=9.9\right)$ and $\mathrm{HOC}_{6} \mathrm{H}_{4}-4-\mathrm{NO}_{2}\left(\mathrm{p} K_{\mathrm{a}}=7.3\right)$. Complexes $1-4$ are obtained in moderate to good yield and are isolated as thermally stable, yellow-orange crystalline solids. In solution the 1,1,1,3,3,3-hexafluoro-2-propoxide complexes 1 and 2 decompose slowly with formation of $\mathbf{P d}^{0}$, whereas the aryloxide complexes 3 and 4 are stable in solution for several months. The decomposition of complexes 1 and 2 probably occurs by $\beta$-hydrogen elimination with formation of an intermediate methyl hydride complex, $[\mathrm{Pd}(\mathrm{H})(\mathrm{Me})(\mathrm{N} \sim \mathrm{N})]$, which undergoes reductive elimination of $\mathrm{CH}_{4}$; related P-ligated alkylpalladium(II) alkoxides are believed to decompose in a similar way. ${ }^{9}$

(13) Alsters, P. L.; Baesjou, P. J.; Janssen, M. D.; Kooijman, H.; SichererRoetman, A.; Spek, A. L.; van Koten, G. Organometallics 1992, 11, 4124.

(14) (a) Kapteijn, G. M.; Grove, D. M.; Smeets, W. J. J.; Spek, A. L.; van Koten, G. Inorg. Chim. Acta 1993, 207, 131. (b) Hunter, C. A.; Lu, X.-J.; Kapteijn, G. M.; van Koten, G. J. Chem. Soc., Faraday Trans. 1995 91,2009 . (c) Recently, the synthesis of tmeda-ligated palladium alkoxide and aryloxide complexes was simultaneously reported by Kim, Y.-J.; Choi, J.-C.: Osakada, K. J. Organomet. Chem. 1995. 491, 97. 


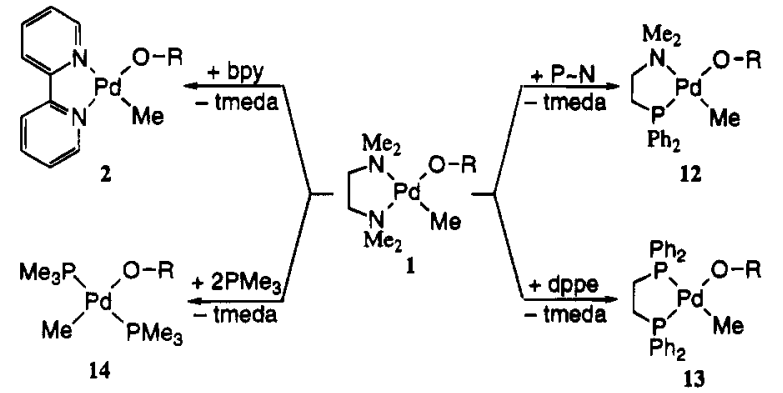

Figure 1. Ligand substitution reactions for methylpalladium alkoxide complex $1\left(\mathrm{R}=\mathrm{CH}\left(\mathrm{CF}_{3}\right)_{2}\right)$ with various donor ligands.

$\beta$-Hydrogen elimination of metal alkoxides is a classical method for the preparation of metal hydrides. ${ }^{15}$

The isolated methylpalladium alkoxide or aryloxide complexes 1-4, when redissolved, react with 1 equiv of $R O H(R$ $\left.=\mathrm{CH}\left(\mathrm{CF}_{3}\right)_{2}, \mathrm{C}_{6} \mathrm{H}_{5}, \mathrm{C}_{6} \mathrm{H}_{4}-4-\mathrm{NO}_{2}\right)$ to give complexes formulated as $[\mathrm{Pd}(\mathrm{Me})(\mathrm{OR})(\mathrm{N} \sim \mathrm{N})] \cdot \mathrm{HOR}(\mathbf{5 - 8})$ as shown in eq 3 . These

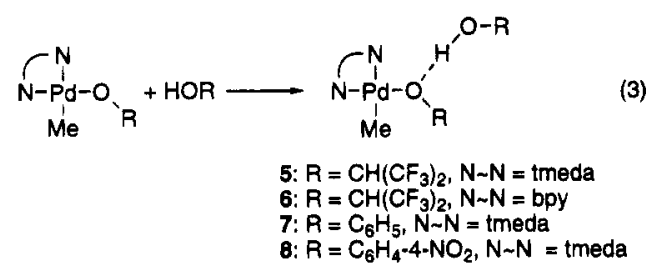

alcohol-associated adducts 5-8 can be isolated, in moderate to good yield, as thermally stable, yellow-orange crystalline solids. The alcohol or phenol free complexes $\mathbf{1 - 4}$ cannot be regenerated from the adducts $\mathbf{5}-\mathbf{8}$ by different workup procedures (see Experimental Section), and this illustrates the stability of the $\mathrm{O}-\mathrm{H} \cdots \mathrm{O}$ hydrogen bond in the latter species. The HOCH$\left(\mathrm{CF}_{3}\right)_{2}$ adducts 5 and 6 are stable in solution and are more thermally robust than the parent complexes 1 and $2 ;$ i.e., the $\mathrm{O}-\mathrm{H} \cdots \mathrm{O}$ hydrogen bond appears to have a positive stabilizing effect. By means of X-ray crystallography and NMR spectroscopy (vide infra) it has indeed proved possible to unambiguously establish that the adducts 5-8 have strong $\mathrm{O}-\mathrm{H} \cdots \mathrm{O}$ hydrogen bonding both in the solid state and in solution.

The $\mathrm{O}-\mathrm{H} \cdots \mathrm{O}$ hydrogen-bonded adducts 5-8 can also be prepared directly by the addition of 2 equiv of alcohol or (substituted) phenol to the corresponding $\mathrm{N}$-ligated dimethylpalladium(II) complexes (eq 4). This route has also been used

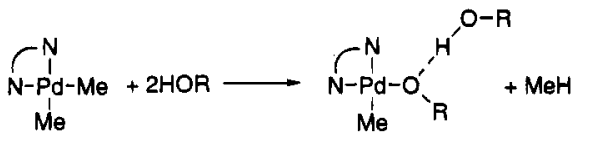

$$
\begin{aligned}
& \text { 5: } \mathrm{R}=\mathrm{CH}\left(\mathrm{CF}_{3}\right)_{2}, \mathrm{~N} \sim \mathrm{N}=\text { tmeda } \\
& \text { 6: } R=C H\left(C F_{3}\right), N \sim N=b p y \\
& \text { 6: } \mathrm{R}=\mathrm{CH}\left(\mathrm{CF}_{3}\right)_{2}, \mathrm{~N} \sim \mathrm{N}=\mathrm{bpy} \\
& \text { 8: } \mathrm{A}=\mathrm{C}_{6} \mathrm{H}_{4} \cdot 4-\mathrm{NO}_{2}, \mathrm{~N} \sim \mathrm{N}=\text { tmeda } \\
& \text { 9: } \mathrm{A}=\mathrm{C}_{6} \mathrm{H}_{5}, \mathrm{~N} \sim \mathrm{N}=\text { bpy } \\
& \text { 10: } A=C_{6} H_{3}-2,4-M e_{2}, N \sim N=\text { tmeda }
\end{aligned}
$$

to prepare the new adducts $\left[\mathrm{Pd}(\mathrm{Me})\left(\mathrm{OC}_{6} \mathrm{H}_{5}\right)(\mathrm{bpy})\right] \cdot \mathrm{HOC}_{6} \mathrm{H}_{5}(9)$ and $\left[\mathrm{Pd}(\mathrm{Me})\left(\mathrm{OC}_{6} \mathrm{H}_{3}-2,4-\mathrm{Me}_{2}\right)(\mathrm{bpy})\right] \cdot \mathrm{HOC}_{6} \mathrm{H}_{3}-2,4-\mathrm{Me}_{2}(10)$. The synthesis of these latter adducts is interesting in that the addition of 1 equiv of phenol or 2,4-dimethylphenol to [ $\left.\mathrm{Pd}(\mathrm{Me})_{2}(\mathrm{bpy})\right]$ does not produce the expected aryloxide complex but $1 / 2$ equiv of the adduct ( 9 or 10) with $1 / 2$ equiv of unreacted starting material. It appears, therefore, that an additional amount of aryl alcohol is needed (accounting for $\mathrm{O}-\mathrm{H} \cdots \mathrm{O}$ hydrogen bonding) in order to drive the palladium aryloxide formation to completion.

(15) Chatt, J.; Shaw, B. L. J. Chem. Soc. 1962, 5075.
The reaction of an equimolar amount of catechol with [Pd$(\mathrm{Me})_{2}$ (tmeda)] produces $\left[\mathrm{Pd}(\mathrm{Me})\left(\mathrm{OC}_{6} \mathrm{H}_{4}-2-\mathrm{OH}\right)(\mathrm{tmeda})\right](11)$ which contains, in addition to the $\mathrm{Pd}-\mathrm{O}$ bond, an intramolecular $\mathrm{O}-\mathrm{H} \cdots \mathrm{O}$ hydrogen bond with the $0-\mathrm{OH}$ group (eq 5). This complex shows properties (vide infra) like those found for the alcohol adducts 5-10 containing intermolecular $\mathrm{O}-\mathrm{H} \cdots \mathrm{O}$ hydrogen bonds.

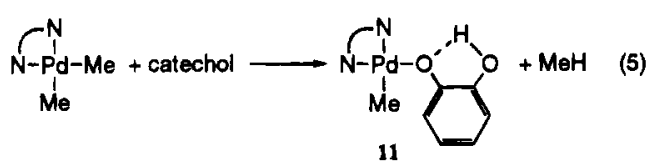

The palladium alkoxide complex $\left[\mathrm{Pd}(\mathrm{Me})\left(\mathrm{OCH}\left(\mathrm{CF}_{3}\right)_{2}\right)-\right.$ (tmeda)] (1) is a useful starting material for the preparation of a variety of methylpalladium(II) fluorinated alkoxide complexes (see Figure 1). In benzene solution the tmeda ligand of 1 is smoothly substituted by bpy, (diphenylphosphino)- $N, N^{\prime}$-dimethylethylenediamine $(\mathrm{P} \sim \mathrm{N})$, or 1,2-bis(diphenylphosphino)ethane (dppe) to produce the fluorinated alkoxide complexes $\left[\mathrm{Pd}(\mathrm{Me})\left(\mathrm{OCH}\left(\mathrm{CF}_{3}\right)_{2}\right)(\mathrm{bpy})\right](2),\left[\mathrm{Pd}(\mathrm{Me})\left(\mathrm{OCH}\left(\mathrm{CF}_{3}\right)_{2}\right)(\mathrm{P} \sim \mathrm{N})\right]^{16}$ (12), and $\left[\mathrm{Pd}(\mathrm{Me})\left(\mathrm{OCH}\left(\mathrm{CF}_{3}\right)_{2}\right)(\mathrm{dppe})\right](13)$, respectively. Reaction of 1 with $\mathrm{PMe}_{3}$ results in the formation of the trans complex $\left[\mathrm{Pd}(\mathrm{Me})\left(\mathrm{OCH}\left(\mathrm{CF}_{3}\right)_{2}\right)\left(\mathrm{PMe}_{3}\right)_{2}\right](14)$. Complexes 13 and 14 have been described before and were identified by comparison of their ${ }^{1} \mathrm{H}$ and ${ }^{31} \mathrm{P}$ NMR spectra with the literature data. ${ }^{10 \mathrm{a}}$ This displacement of tmeda in 1 by other ligands confirms the excellent applicability of tmeda-ligated palladium complexes as versatile starting materials for the preparation of a large variety of palladium(II) complexes. ${ }^{17}$ Surprisingly, the attempted substitution of the tmeda ligand in the aryloxide complex $\left[\mathrm{Pd}(\mathrm{Me})\left(\mathrm{OC}_{6} \mathrm{H}_{5}\right)(\right.$ tmeda) $(3)$ for other ligands failed and the starting materials were recovered.

An alternative route for the preparation of the fluorinated alkoxide complex $\left[\mathrm{Pd}(\mathrm{Me})\left(\mathrm{OCH}\left(\mathrm{CF}_{3}\right)_{2}\right)(\mathrm{bpy})\right](2)$ involves the reaction of a palladium complex cation, $[\mathrm{Pd}(\mathrm{Me})(\mathrm{MeCN})$ (bpy) $]^{+}$, with $\mathrm{NaOCH}\left(\mathrm{CF}_{3}\right)_{2}$ (eq 6). A conceptually similar

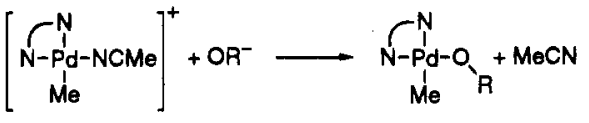

$$
\begin{aligned}
& \text { 2: } \mathrm{R}=\mathrm{CH}\left(\mathrm{CF}_{3}\right)_{2}, \mathrm{~N}-\mathrm{N}=\text { bpy }
\end{aligned}
$$

reaction of an acetone-solvated platinum cation with $\mathrm{KOH}$ was employed by Bennett et al. to prepare interesting methyl(hydroxo)platinum(II) complexes. ${ }^{18}$ An important advantage of the "palladium complex cation" route depicted in eq 6 is that methylpalladium(II) alkoxide complexes are generated without any risk of contamination by the corresponding alcohol adduct. The routes described in eqs $2-5$, using dimethylpalladium(II) complexes as starting materials all require use of exactly equimolar amounts of the alcohol as even a small excess immediately leads to the formation of $\mathrm{O}-\mathrm{H} \cdots \mathrm{O}$ hydrogenbonded species. Unfortunately, this palladium complex cation route has so far only been successfully applied for the synthesis of 2,2'-bipyridine-coordinated methylpalladium(II) alkoxide complexes; when the bidentate $\mathrm{N}$-ligand tmeda is used, this method leads to the formation of palladium metal and unidentified organic products.

(16) An alternative synthesis of $\mathbf{1 2}$ comprises the reaction of HOCH$\left(\mathrm{CF}_{3}\right)_{2}$ with $\left[\mathrm{Pd}(\mathrm{Me})_{2}(\mathrm{P} \sim \mathrm{N})\right]$ : Kapteijn, G. M.; Spee, M. P. R.; Spek, A. L.; Grove, D. M.; van Koten, G. Unpublished results.

(17) (a) de Graaf, W.; Boersma, J.; Smeets, W. J. J.; Spek, A. L.; van Koten, G. Organometallics 1989, 8, 2907. (b) de Graaf, W.; Boersma, J.; van Koten, G. Organometallics 1990, 9, 1479. (c) Markies, B. A.; Rietveld, M. H. P.; Boersma, J.; Spek, A. L.; van Koten, G. J. Organomet. Chem. 1992, 424, C12.

(18) (a) Appleton, T. G.; Bennett, M. A. Inorg. Chem. 1978, 17, 738 (b) Arnold, D. P.; Bennett, M. A. J. Organomet. Chem. 1980, 199, 119. 


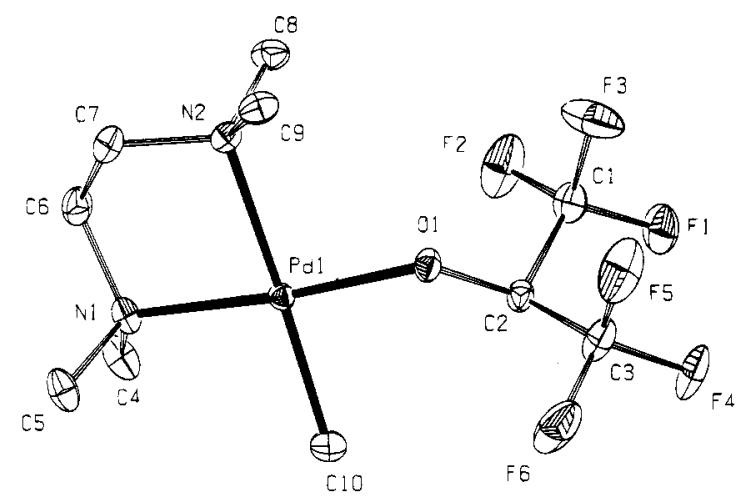

Figure 2. ORTEP ( $30 \%$ probability level) drawing of $\mathbf{1}$.

Molecular Structures of Methylpalladium Alkoxide or Aryloxide Complexes 1,3, and 4 and the $\mathrm{O}-\mathrm{H} \cdots \mathrm{O}$ HydrogenBonded Adducts 7 and 8. Figure 2 shows the molecular structure of the fluorinated alkoxide complex $[\mathrm{Pd}(\mathrm{Me})(\mathrm{OCH}-$ $\left.\left.\left(\mathrm{CF}_{3}\right)_{2}\right)(\mathrm{tmeda})\right](1)$, and Figure 3 shows the molecular structures of the aryloxide complexes $\left[\mathrm{Pd}(\mathrm{Me})\left(\mathrm{OC}_{6} \mathrm{H}_{4}-4-\mathrm{NO}_{2}\right)\right.$ (tmeda)] (4) and $\left[\mathrm{Pd}(\mathrm{Me})\left(\mathrm{OC}_{6} \mathrm{H}_{4}-4-\mathrm{NO}_{2}\right)\right.$ (tmeda) $] \cdot \mathrm{HOC}_{6} \mathrm{H}_{4}-4-\mathrm{NO}_{2}(8)$, respectively. Selected bond lengths and angles for the complexes $1,3,4,7$, and 8 are summarized in Table 1 .

All five complexes possess an approximate square-planar coordination geometry with adjacent, interligand angles around the palladium centers falling in the range $84.6(2)-91.7(1)^{\circ}$. A special feature of complex 1 is that the proton of the $\mathrm{OCH}-$ $\left(\mathrm{CF}_{3}\right)_{2}$ moiety is oriented toward the middle of the $\mathrm{Pd}-\mathrm{CH}_{3}$ bond and the distance of this proton from palladium $(d(\mathrm{Pd} \cdots \mathrm{H})$ $=2.89(2) \AA$ ) is slightly smaller than the sum of the van der Waals radii. This separation may be regarded as the incipient stage of a $\beta$-hydrogen elimination, involving transfer of the proton from the $\mathrm{OCH}\left(\mathrm{CF}_{3}\right)_{2}$ moiety to the metal center that would afford a palladium hydride and hexafluoroacetone. The molecular structure of 1 also reveals the presence of a possible electrostatic $\mathrm{C}-\mathrm{H} \cdots \mathrm{O}$ interaction from a NMe group with the oxygen of the $\mathrm{OCH}\left(\mathrm{CF}_{3}\right)_{2}$ unit $(d[\mathrm{C}(9)-\mathrm{H}(9) \cdots \mathrm{O}(1)]=3.106-$ (4) $\AA$ ). This type of interaction may be termed a steering interaction which, although small in energy $\left(1-2 \mathrm{kcal} \mathrm{mol}^{-1}\right)$, is sufficient to select a preferred molecular conformation..$^{19} \mathrm{We}$ have reported earlier another example of a $\mathrm{C}-\mathrm{H} \cdots \mathrm{O}$ interaction in a mixed alkoxo(aryloxo)palladium(II) complex. ${ }^{14 a}$

Complexes 7 and 8 show the association of phenol or $p$-nitrophenol, respectively, to the aryloxide ligand through $\mathrm{O}-\mathrm{H} \cdots \mathrm{O}$ hydrogen bonding $(d(\mathrm{O} \cdots \mathrm{O})=2.575(3)$ and 2.631 (4) Å, respectively). Hydrogen bonds are referred to as strong when the $O \cdots O$ distance is in the range $2.50-2.65 \AA,{ }^{11 e}$ and on this basis we conclude that the $\mathrm{O}-\mathrm{H} \cdots \mathrm{O}$ interaction in 7 and $\mathbf{8}$ is reasonably strong. The distance between the two oxygen atoms of $\mathbf{7}$ and $\mathbf{8}$ is comparable to $\mathrm{O} \cdot \cdots \mathrm{O}$ distances both in organic molecules displaying hydrogen bonding ${ }^{11}$ and in some other late transition metal alkoxide adducts (see Table 2). The $\mathrm{Pd}-\mathrm{O}$ distances in the nonassociated complexes $1, \mathbf{3}$, and $\mathbf{4}$ $(2.020(2), 2.024(3)$, and $2.029(4) \AA$, respectively) fall within the range of $\mathrm{Pd}-\mathrm{O}$ distances found in related palladium alkoxide and aryloxide complexes (see Table 2). The phenol and $p$-nitrophenol adducts 7 and $\mathbf{8}$ show $\mathrm{Pd}-\mathrm{O}$ distances of 2.037 (2) and 2.043(2) $\AA$, respectively; i.e., association of an alcohol

(19) Desiraju, G. R. Acc. Chem. Res. 1991, 24, 290.

(20) Structures of palladium bis(alkoxides) based on diethanolamines ( $\left.\mathrm{RN}\left(\mathrm{CH}_{2} \mathrm{CH}_{2} \mathrm{OH}\right)_{2}\right)$ show the formation of either intra- or intermolecular $\mathrm{O}-\mathrm{H} \cdots \mathrm{O}$ hydrogen bonds to depend on the $\mathrm{R}$ substituent $(\mathrm{R}=\mathrm{Me}$, inter; $\mathrm{R}=\mathrm{CH}_{2} \mathrm{CH}_{2} \mathrm{OH}$, intra): Kapteijn, G. M.; Grove, D. M.; van Koten, G. Unpublished results.

(21) (a) Simpson, R. D.; Bergman, R. G. Organometallics 1993, 12, 781 (b) Osakada. K.; Takizawa, T.: Tanaka, M.; Yamamoto, T. J. Organomet Chem. 1994, 473, 359. causes a small lengthening of the $\mathrm{Pd}-\mathrm{O}$ bond by $\sim 0.013 \AA$. A similar elongation of the $\mathrm{Pd}-\mathrm{O}$ bond upon adduct formation has been reported by $\mathrm{Kim}$ et al. for trans-[Pd(Me) $\left(\mathrm{OC}_{6} \mathrm{H}_{5}\right)$ $\left.\left(\mathrm{PMe}_{3}\right)_{2}\right]$ with phenol. ${ }^{10 \mathrm{a}}$ Another geometrical parameter which is sensitive to $\mathrm{O}-\mathrm{H} \cdots \mathrm{O}$ bond formation is the $\mathrm{C}-\mathrm{O}$ bond length of the aryloxide ligand. In the adducts 7 and $\mathbf{8}$ this bond is longer by 0.022 and $0.034 \AA$, respectively, than the corresponding bond in the alcohol free complexes 3 and 4 . The presence of a $\mathrm{NO}_{2}$ substituent on the aromatic ring also influences the $\mathrm{C}-\mathrm{O}$ bond length $(d(\mathrm{C}-\mathrm{O})$ values for $\mathbf{3}$ and $\mathbf{4}$ are 1.314(6) and $1.286(6) \AA$, respectively) as a result of resonance and inductive effects. In all tmeda complexes $1,3,4,7$, and 8 studied here the $\mathrm{Pd}-\mathrm{N}(2)$ bond trans to the methyl group (range: $2.178(3)-2.194(2) \AA$ ) is considerably longer than the $\mathrm{Pd}-\mathrm{N}(1)$ bond $c i s$ to the methyl group (range: $2.060(5)-2.080$ (2) $\AA$ ), reflecting the larger trans influence of the methyl ligand as compared with the alkoxide (or phenoxide) ligands.

Association of Alcohol with Methylpalladium Alkoxide or Phenoxide Complexes. IR spectra of the hydrogen-bonded complexes 5-10 in $\mathrm{KBr}$ disks show a broad peak at 2350$2750 \mathrm{~cm}^{-1}$. This absorption corresponds to $v(\mathrm{O}-\mathrm{H})$ vibration of the hydrogen-bonded $\mathrm{OH}$ group in the aryl or fluorinated alcohol, and its value is indicative of a medium to strong hydrogen bond. ${ }^{11}$ In order to quantify the strength of these hydrogen bonds in solution we determined the equilibrium constants $\left(K_{\text {ass }}\right)$ for the association of 1,1,1,3,3,3-hexafluoro-2propanol or phenol with methylpalladium complexes $[\mathrm{Pd}(\mathrm{Me})$ $\left(\mathrm{OCH}\left(\mathrm{CF}_{3}\right)_{2}\right)$ (tmeda)] $(\mathbf{1})$ or $\left[\mathrm{Pd}(\mathrm{Me})\left(\mathrm{OC}_{6} \mathrm{H}_{5}\right)\right.$ (tmeda) $(3)$ (see eq 1) with application of the Scatchard equation to ${ }^{1} \mathrm{H}$ NMR data obtained at various temperatures. ${ }^{22}$ This method is based on the change of the chemical shift of the $\mathrm{OH}$ resonance (at a fixed concentration of hydrogen-bond donor) with variation of the concentration of the hydrogen-bond acceptor (i.e., palladium alkoxide or phenoxide). An important condition made in the derivation of the Scatchard equation is that the ratio of the concentration of palladium alkoxide (or phenoxide) complex to that of alcohol (or phenol) is high (typically $>15: 1$ ). This condition in combination with the low boiling point of $\mathrm{CDCl}_{3}$ makes it difficult in practice to achieve a wide range of saturation factors. The ${ }^{1} \mathrm{H}$ NMR spectra of mixtures of 1,1,1,3,3,3-hexafluoro-2-propanol (fixed at $0.012 \mathrm{M}$ ) and $\mathbf{1}$ ([complex]/[alcohol] ranges from 15 to 35 ) or phenol (fixed at $0.010 \mathrm{M}$ ) and 3 ([complex]/[phenol] ranges from 18 to 40 ) in $\mathrm{CDCl}_{3}$ show the $\mathrm{O}-\mathrm{H}$ resonance in the range $9.7-7.9 \mathrm{ppm}$. This $\mathrm{OH}$ resonance shifts to higher field upon raising the temperature or on decreasing the concentration of palladium alkoxide (or phenoxide). Thermodynamic parameters for the association have been derived from the temperature dependence of the equilibrium constant $\left(K_{\text {ass }}\right)$ through use of a van't Hoff plot in which $\ln K_{\text {ass }}$ is plotted against $1 / T$. The resulting plots for the association of 1,1,1,3,3,3-hexafluoro-2-propanol to 1 and phenol to 3 are shown in Figure 4. The thermodynamic parameters obtained from Figure 4 for association of 1,1,1,3,3,3hexafluoro-2-propanol to 1 (at $298 \mathrm{~K}$ ) are $\Delta H^{\circ}=-34.7 \pm 2.6$ $\mathrm{kJ} \mathrm{mol}{ }^{-1}, \Delta S^{\circ}=83.6 \pm 8.1 \mathrm{~J} \mathrm{~K}^{-1} \mathrm{~mol}^{-1}$, and $K_{\text {ass }}=53 \mathrm{~L}$ $\mathrm{mol}^{-1}\left(\Delta G^{\circ}=-9.9 \pm 3.6 \mathrm{~kJ} \mathrm{~mol}^{-1}\right)$, whereas values for phenol association to 3 (at $298 \mathrm{~K}$ ) are $\Delta H^{\circ}=-29.1 \pm 2.4 \mathrm{~kJ} \mathrm{~mol}^{-1}$, $\Delta S^{\circ}=58.6 \pm 7.4 \mathrm{~J} \mathrm{~K}^{-1} \mathrm{~mol}^{-1}$, and $K_{\text {ass }}=105 \mathrm{~L} \mathrm{~mol}^{-1}\left(\Delta G^{\circ}\right.$ $\left.=-11.6 \pm 3.3 \mathrm{~kJ} \mathrm{~mol}^{-1}\right)$. The unequality affinity for $\mathrm{O}-\mathrm{H} \cdots \mathrm{O}$ bond formation in 1 and 3 as expressed in the $K_{\text {ass }}$ values can be seen to derive from very different $\Delta S^{\circ}$ values. The enthalpy data indicate that the hydrogen bonds observed for $\mathbf{1}$ and $\mathbf{3}$ are both strong when compared to the intermolecular $\mathrm{O}-\mathrm{H} \cdots \mathrm{O}$ hydrogen bonding of aliphatic alcohols $\left(\Delta H^{\circ}=-12\right.$ to -25 $\left.\mathrm{kJ} \mathrm{mol}^{-1}\right) .{ }^{11}$ An overview of thermodynamic parameters

(22) See ref $11 b, p 173$. 

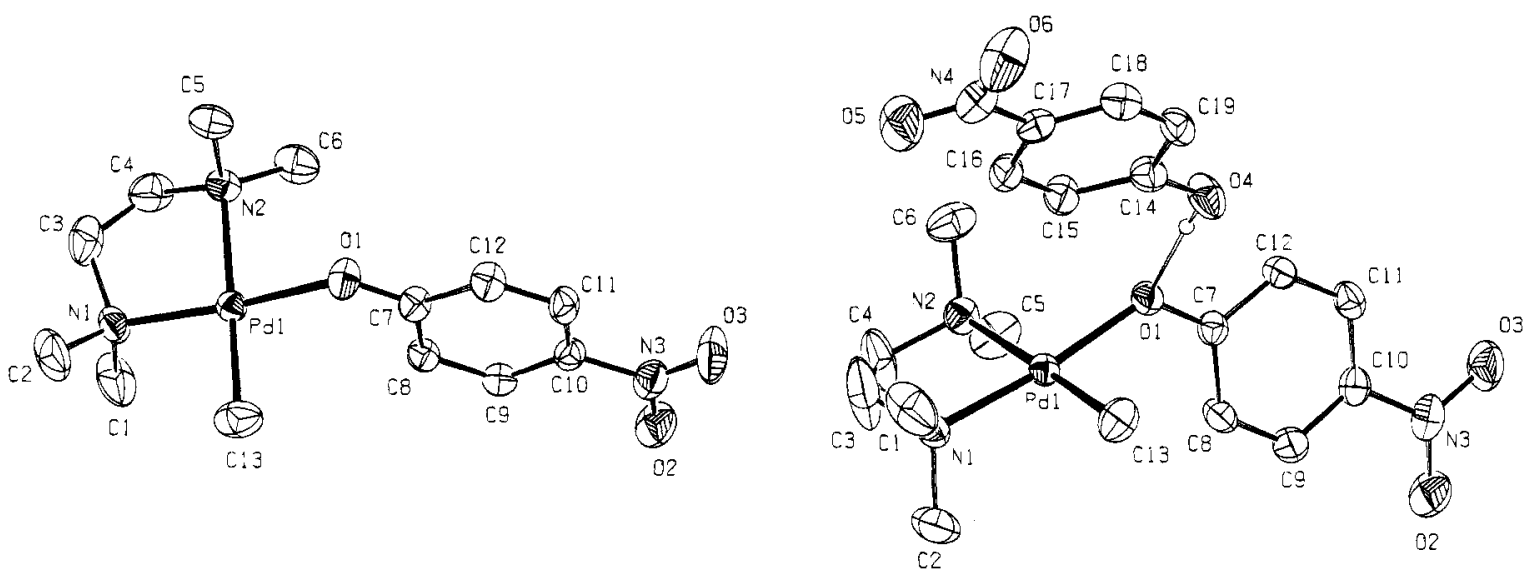

Figure 3. ORTEP (30\% probability level) drawings of 4 (left) and 8 (right).

Table 1. Selected Bond Distances $(\AA)$, Bond Angles (deg), and Dihedral Angles (deg) for the Complexes $[\mathrm{Pd}(\mathrm{Me})(\mathrm{OR})(\mathrm{tmeda})](\mathbf{1}, \mathbf{3}$, and 4) and their Adducts $[\mathrm{Pd}(\mathrm{Me})(\mathrm{OR})(\mathrm{tmeda})] \cdot \mathrm{HOR}(\mathbf{7} \text { and } \mathbf{8})^{a}$

\begin{tabular}{|c|c|c|c|c|c|}
\hline & $1\left(\mathrm{R}=\mathrm{CH}\left(\mathrm{CF}_{3}\right)_{2}\right)$ & $3\left(\mathrm{R}=\mathrm{C}_{6} \mathrm{H}_{5}\right)$ & $7\left(\mathrm{R}=\mathrm{C}_{6} \mathrm{H}_{5}\right)$ & $4\left(\mathrm{R}=\mathrm{C}_{6} \mathrm{H}_{4}-4-\mathrm{NO}_{2}\right)$ & $8\left(\mathrm{R}=\mathrm{C}_{6} \mathrm{H}_{4}-4-\mathrm{NO}_{2}\right)$ \\
\hline \multicolumn{6}{|c|}{ Bond Distances } \\
\hline $\mathrm{Pd}-\mathrm{O}$ & $2.020(2)$ & $2.024(3)$ & $2.037(2)$ & $2.029(4)$ & $2.043(2)$ \\
\hline $\mathrm{Pd}-\mathrm{C}$ & $2.017(3)$ & $2.010(5)$ & $2.025(3)$ & $1.997(7)$ & $2.012(4)$ \\
\hline $\mathrm{Pd}-\mathrm{N}(1)$ & $2.080(2)$ & $2.071(4)$ & $2.071(2)$ & $2.060(5)$ & $2.072(3)$ \\
\hline $\mathrm{Pd}-\mathrm{N}(2)$ & $2.183(2)$ & $2.178(3)$ & $2.194(2)$ & $2.178(5)$ & $2.181(3)$ \\
\hline $\mathrm{C}-\mathrm{O}^{b}$ & $1.365(3)$ & $1.314(6)$ & $1.336(4)$ & $1.286(6)$ & $1.320(4)$ \\
\hline $\mathrm{C}-\mathrm{O}^{c}$ & & & $1.349(3)$ & & $1.347(4)$ \\
\hline $0 \cdots 0$ & & & $2.575(3)$ & & $2.631(4)$ \\
\hline \multicolumn{6}{|c|}{ Bond Angles } \\
\hline $\mathrm{Pd}-\mathrm{O}-\mathrm{C}$ & $121.8(1)$ & $122.8(3)$ & $122.0(2)$ & $125.5(3)$ & $125.2(2)$ \\
\hline $\mathrm{C}-\mathrm{Pd}-\mathrm{O}$ & $91.71(9)$ & $88.4(2)$ & $89.4(1)$ & $89.6(2)$ & $89.4(1)$ \\
\hline $\mathrm{N}-\mathrm{Pd}-\mathrm{N}$ & $84.94(7)$ & $84.6(2)$ & $84.9(1)$ & $85.6(2)$ & $85.1(1)$ \\
\hline $\mathrm{O}-\mathrm{H} \cdots \mathrm{O}$ & & & $167(2)$ & & $176(5)$ \\
\hline \multicolumn{6}{|c|}{ Dihedral Angles } \\
\hline $\mathrm{N}-\mathrm{C}-\mathrm{C}-\mathrm{N}$ & $-56.7(3)$ & $-54.1(7)$ & $56.3(4)$ & $-55.4(7)$ & $34.7(9)$ \\
\hline $\mathrm{Pd}-\mathrm{O}-\mathrm{C}-\mathrm{C}$ & & $25.4(6)$ & $-29.6(3)$ & $0.8(7)$ & $1.1(5)$ \\
\hline
\end{tabular}

${ }^{a}$ Numbers in parentheses are estimated standard deviations in the least significant digits. ${ }^{b}$ Alkoxide or aryloxide oxygen. ${ }^{c}$ (Aryl) alcohol oxygen.

Table 2. Overview of Characteristic Bond Distances and Angles of Transition Metal Alkoxide or Aryloxide Adducts

\begin{tabular}{|c|c|c|c|c|c|}
\hline entry & compound & $d(\mathrm{O} \cdots \mathrm{O})(\AA)$ & $\angle(\mathrm{O}-\mathrm{H} \cdots \mathrm{O})(\mathrm{deg})$ & $d(\mathrm{M}-\mathrm{O})(\AA)$ & ref \\
\hline \multicolumn{6}{|c|}{ Palladium(II) Alkoxides and Aryloxides } \\
\hline 1 & {$\left[\mathrm{Pd}(\mathrm{OPh})\left(\mathrm{C}_{6} \mathrm{H}_{3}\left\{\mathrm{CH}_{2} \mathrm{NMe}_{2}\right\}_{2}-2,6\right)\right] \cdot \mathrm{HOPh}$} & $2.567(6)$ & & $2.139(4)$ & 13 \\
\hline 2 & {$[\mathrm{Pd}(\mathrm{Me})(\mathrm{OPh})(\mathrm{tmeda})] \cdot \mathrm{HOPh}$} & $2.575(3)$ & 167 & $2.037(2)$ & this work \\
\hline 3 & trans- $\left[\mathrm{Pd}(\mathrm{H})\left(\mathrm{OC}_{6} \mathrm{~F}_{5}\right)\left(\mathrm{PCy}_{3}\right)_{2}\right] \cdot \mathrm{HOC}_{6} \mathrm{~F}_{5}$ & $2.59(3)$ & 164.7 & $2.181(2)$ & $10 \mathrm{e}$ \\
\hline 4 & trans $-\left[\mathrm{Pd}(\mathrm{Me})(\mathrm{OPh})\left(\mathrm{PMe}_{3}\right)_{2}\right] \cdot \mathrm{HOPh}$ & $2.593(4)$ & 169.9 & $2.134(3)$ & $10 \mathrm{a}$ \\
\hline 5 & trans $-\left[\mathrm{Pd}(\mathrm{Me})(\mathrm{OPh})\left(\mathrm{PMe}_{3}\right)_{2}\right] \cdot \mathrm{HOCH}\left(\mathrm{CF}_{3}\right)(\mathrm{Ph})$ & $2.601(4)$ & 165.4 & $2.107(2)$ & $10 \mathrm{a}$ \\
\hline 6 & {$\left[\mathrm{Pd}(\mathrm{Me})\left(\mathrm{OC}_{6} \mathrm{H}_{4}-\mathrm{NO}_{2}\right)(\mathrm{tmeda})\right] \cdot \mathrm{HOC}_{6} \mathrm{H}_{4}-\mathrm{NO}_{2}$} & $2.631(4)$ & 176 & $2.043(2)$ & this work \\
\hline 7 & trans $\left.-\left[\mathrm{Pd}(\mathrm{OPh})_{2} \text { (pyrrolidine }\right)_{2}\right] \cdot 2 \mathrm{HOPh}$ & $2.638(4)$ & & $2.018(2)$ & 13 \\
\hline 8 & trans $-\left[\mathrm{Pd}(\mathrm{H})(\mathrm{OPh})\left(\mathrm{PCy}_{3}\right)_{2}\right] \cdot \mathrm{HOPh}$ & $2.64(4)$ & 168.3 & $2.135(2)$ & $10 \mathrm{e}$ \\
\hline 9 & {$\left[\mathrm{Pd}(\mathrm{OPh})\left(\mathrm{OCH}\left(\mathrm{CF}_{3}\right)_{2}\right)(\mathrm{bpy})\right] \cdot \mathrm{HOPh}^{a}$} & $2.642(8)$ & & $1.997(5)$ & 14 \\
\hline 10 & {$\left[\mathrm{Pd}\left(\mathrm{OCH}_{2} \mathrm{CH}_{2} \mathrm{~N}(\mathrm{Me})\left(\mathrm{CH}_{2} \mathrm{CH}_{2} \mathrm{OH}\right)_{2}\right]^{b}\right.$} & $2.652(5)$ & 177.0 & $2.002(3)$ & 20 \\
\hline 11 & {$\left[\mathrm{Pd}\left(\mathrm{OCH}_{2} \mathrm{CH}_{2} \mathrm{~N}\left(\mathrm{CH}_{2} \mathrm{CH}_{2} \mathrm{OH}\right)_{2}\right)_{2}\right]$} & $2.665(5)$ & 167.0 & $2.006(3)$ & 20 \\
\hline \multicolumn{6}{|c|}{ Other Transition Metal Alkoxides and Aryloxides } \\
\hline 12 & $\mathrm{fac}-\left[(\mathrm{CO})_{3}(\mathrm{depe}) \operatorname{Re}\left(\mathrm{OCH}_{2} \mathrm{CH}_{3}\right)\right] \cdot \mathrm{HOC}_{6} \mathrm{H}_{4}-4-\mathrm{Me}$ & $2.532(5)$ & 173.2 & $2.154(3)$ & $21 \mathrm{a}$ \\
\hline 13 & trans- $\left[\mathrm{Ni}(\mathrm{H})(\mathrm{OPh})\left(\mathrm{PBz}_{3}\right)_{2}\right] \cdot \mathrm{HOPh}$ & $2.544(6)$ & & $1.949(4)$ & $10 \mathrm{i}$ \\
\hline 14 & {$\left[\mathrm{Pt}\left(\mathrm{OC}_{6} \mathrm{H}_{4}-2-\mathrm{OH}\right)\left(\mathrm{C}_{6} \mathrm{H}_{3}\left\{\mathrm{CH}_{2} \mathrm{NMe}_{2}\right\}_{2}-2,6\right)\right]^{c}$} & $2.57(2)$ & 117.0 & $2.10(2)$ & $16 \mathrm{~b}$ \\
\hline 15 & trans $-\left[\mathrm{Ni}(\mathrm{Me})(\mathrm{OPh})\left(\mathrm{PMe}_{3}\right)_{2}\right] \cdot \mathrm{HOPh}$ & $2.602(8)$ & 165.6 & $1.932(5)$ & $10 \mathrm{a}$ \\
\hline 16 & $\left.\left[\mathrm{Rh}\left(\mathrm{OC}_{6} \mathrm{H}_{4}-4-\mathrm{Me}\right)\left(\mathrm{PMe}_{3}\right)_{3}\right)\right] \cdot \mathrm{HOC}_{6} \mathrm{H}_{4}-4-\mathrm{Me}$ & $2.62(5)$ & & & $10 \mathrm{~b}$ \\
\hline 17 & {$\left[\mathrm{Pt}(\mathrm{Me})\left(\mathrm{OCH}\left(\mathrm{CF}_{3}\right)_{2}\left(\mathrm{PMe}_{3}\right)_{2}\right] \cdot \mathrm{HOCH}\left(\mathrm{CF}_{3}\right)_{2}\right.$} & $2.63(5)$ & & $2.07(3)$ & $10 \mathrm{k}$ \\
\hline 18 & {$\left[\mathrm{Ru}\left(\mathrm{OCH}_{2} \mathrm{C}_{6} \mathrm{H}_{4}\right)\left(\mathrm{PMe}_{3}\right)_{4}\right] \cdot \mathrm{HOCH}_{2} \mathrm{C}_{6} \mathrm{H}_{4}$} & $2.75(2)^{d}$ & & $2.144(8)$ & $10 \mathrm{j}$ \\
\hline
\end{tabular}

${ }^{a}$ The oxygen coordinated to $\mathrm{Pd}$ is also taking part in a $\mathrm{C} \rightarrow \mathrm{H} \cdots \mathrm{O}$ hydrogen bond. ${ }^{b}$ Intermolecular $\mathrm{O}-\mathrm{H} \cdots \mathrm{O}$ hydrogen bonds result in a twodimensional molecular network. ${ }^{c}$ The unusually acute $\mathrm{O}-\mathrm{H} \cdots \mathrm{O}$ angle is a result of an intramolecular $\mathrm{O}-\mathrm{H} \cdots \mathrm{O}$ hydrogen bond. ${ }^{d}$ This distance is probably a result of the high $\mathrm{p} K_{\mathrm{a}}$ value for benzyl alcohol.

obtained using calorimetric titration or the Scatchard method for the association of alcohols with some late transition metal alkoxides or aryloxides is shown in Table 3. This table includes the enthalpy values of $\mathrm{O}-\mathrm{H} \cdots \mathrm{O}$ hydrogen bond formation not only for late transition metal mono(alkoxide) complexes (entries $1-3$ and $6-10$ ) but also for late transition metal bis(aryloxide) complexes (entries 4 and 5). For several palladium and platinum complexes (entries $3-6$ and $9-10$ in Table 3 ) the $\Delta H^{\circ}$ values are in the range -17 to $-25 \mathrm{~kJ} \mathrm{~mol}^{-1}$ even though there is a large variety of $\mathrm{C}, \mathrm{O}$, and $\mathrm{P}$ donors present trans to the alkoxide ligand. This indicates that strong trans-positioned $\sigma$-donors are not a prerequisite for strong $\mathrm{O}-\mathrm{H} \cdots \mathrm{O}$ hydrogen bonding and that the strength is determined by other factors as well. ${ }^{13}$ The enthalpy values obtained by us for association of an alcohol 


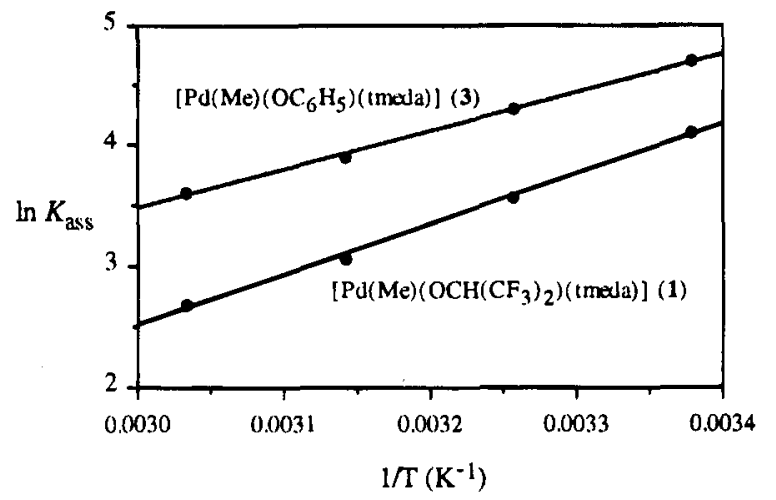

Figure 4. Van't Hoff plots for association of HOR to $\mathbf{1}$ and $\mathbf{3}$.

with both $\left[\mathrm{Pd}(\mathrm{Me})\left(\mathrm{OCH}\left(\mathrm{CF}_{3}\right)_{2}\right)(\right.$ tmeda $\left.)\right](1)$ and $[\mathrm{Pd}(\mathrm{Me})$ $\left(\mathrm{OC}_{6} \mathrm{H}_{5}\right)$ (tmeda)] (3) in $\mathrm{CDCl}_{3}$ are substantially higher than those obtained for other palladium and platinum alkoxides. However, our values are lower than for association of $\mathrm{HOC}_{6} \mathrm{H}_{4}-4-\mathrm{Me}$ to the rhodium(I) aryloxide complex $\left[\mathrm{Rh}\left(\mathrm{OC}_{6} \mathrm{H}_{4}-4-\mathrm{Me}\right)\left(\mathrm{PMe}_{3}\right)_{2}\right]$ in benzene (entry 8 ) or cyclohexane (entry 7), and a possible explanation could lie in polarity differences between the solvents used in these two studies. ${ }^{19,23}$ The $\Delta H^{\circ}$ differences for $\mathrm{O}-\mathrm{H} \cdots \mathrm{O}$ hydrogen-bond formation of diamine (tmeda) chelate complexes 1 and 3 with alcohol or phenol are significantly higher $\left(\sim 10 \mathrm{~kJ} \mathrm{~mol}^{-1}\right)$ than those reported for analogous phosphine-ligated palladium alkoxides and phenoxides (entry 3 and 6). We believe that in complexes 1 and 3 the purely $\sigma$-donating amine ligand tmeda increases the nucleophilicity of the metal center more than a phosphine does and this leads to a higher negative charge on the oxygen atom of the alkoxide or phenoxide unit and, consequently, to the formation of stronger $\mathrm{O}-\mathrm{H} \cdots \mathrm{O}$ hydrogen bonds. The reason that the phenoxide complex 3 produces a smaller enthalpy value for $\mathrm{O}-\mathrm{H} \cdots \mathrm{O}$ hydrogen bond formation than the alkoxide complex 1 is almost certainly due to distribution of the negative charge of the oxygen atom over the aromatic ring by resonance stabilization. It is known that charged delocalized anions, including phenoxide, form weaker hydrogen bonds than nondelocalized anions. ${ }^{24}$ Thus, the strength of the $\mathrm{O}-\mathrm{H} \cdots \mathrm{O}$ hydrogen bond in organometallic alkoxide or aryl oxide complexes is governed by two factors, firstly the $\sigma$-donor strength of the group in the trans position with respect to the OR unit (a stronger $\sigma$-donor affords a stronger $\mathrm{O}-\mathrm{H} \cdots \mathrm{O}$ hydrogen bond) and secondly charge delocalization within the $-O R$ fragment (reducing the strength of the $\mathrm{O}-\mathrm{H} \cdots \mathrm{O}$ hydrogen bond).

Enthalpy versus Entropy in Adduct Formation. There is now a reliable set of thermodynamic parameters for alcohol association to late transition metal alkoxide complexes in chlorocarbon solvents (see Table 3), and as shown in Figure 5 these data provide a reasonable straight line correlation between $\Delta H^{\circ}$ and $\Delta S^{\circ}$ for formation of transition metal alkoxide adducts with $\Delta S^{\circ}=4.04 \Delta H^{\circ}+54.4\left(\Delta H^{\circ}\right.$ in $\left.\mathrm{kJ} \mathrm{mol}^{-1}, r^{2}=0.90\right)$.

In organic chemistry several authors have demonstrated that there is a monotonic relationship between $\Delta H^{\circ}$ and $\Delta S^{\circ}$ for $\mathrm{O}-\mathrm{H} \cdots \mathrm{O}$ hydrogen-bond formation between alcohols and other organic compounds such as aldehydes, ketones, esters, amines, and amides $\left(r^{2}=0.69-0.93\right) .^{11 c}$ Shepp and Bauer have postulated that the observed linear relationships can be explained in the following way. ${ }^{25}$ On formation of an intermolecular $\mathrm{O}-\mathrm{H} \cdot \cdots \mathrm{O}$ hydrogen bond (eq 1) there will be a loss of entropy $\left(\Delta S^{\circ}\right)$ which can be regarded as being made up of two separate

(23) Chloroform can form $\mathrm{C}-\mathrm{H} \cdots \mathrm{O}$ bonds: Green, R. D. Hydrogen Bonding in C-H Groups; Macmillan: London, 1974.

(24) Meor-Ner, M.; Sieck, L. W. J. Am. Chem. Soc. 1986, 108, 7525.

(25) Shepp, B.; Bauer, K. J. Am. Chem. Soc. 1954, 76, 265.

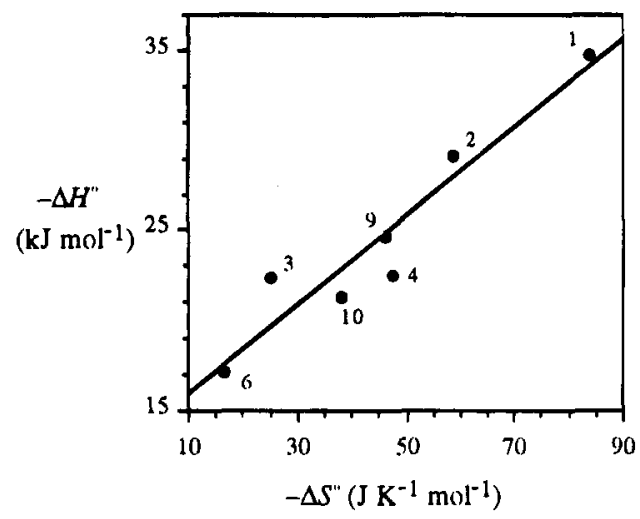

Figure 5. Plot of $-\Delta H^{\circ}$ vs $-\Delta S^{\circ}$ for alcohol $\mathrm{O}-\mathrm{H} \cdots \mathrm{O}$ hydrogen bonds to late transition metal alkoxides. The entries are summarized in Table 3.

terms, $\Delta S_{\text {trans }}$ and $\Delta S_{\text {internal }}$ (eq 7). $\Delta S_{\text {trans }}$ is negative because

$$
\Delta S^{\circ}=\Delta S_{\text {trans }}+\Delta S_{\text {internal }}
$$

of the loss of degrees of translational freedom which makes the major contribution to the observed entropy of the reaction. However, $\Delta S_{\text {internal }}$ should be positive because of the gain of new rotational and vibrational freedom as a consequence of the formation of a new $(\mathrm{O}-\mathrm{H} \cdots \mathrm{O})$ bond. On the one hand, if the new $\mathrm{O}-\mathrm{H} \cdots \mathrm{O}$ hydrogen bond is strong, then the force constants describing the new internal vibrations will be large and the $\Delta S_{\text {internal }}$ associated with them will be relatively small, leading to a large overall negative $\Delta S^{\circ}$. On the other hand, weak $\mathrm{O}-\mathrm{H} \cdots \mathrm{O}$ hydrogen bonds will produce a large gain in $\Delta S_{\text {internal, }}$, which cancels the $\Delta S_{\text {trans, }}$, producing a small overall negative $\Delta S^{\circ}$. This postulate, which is valid for hydrogen bonds in organic molecules, now also seems correct for the formation of $\mathrm{O}-\mathrm{H} \cdots \mathrm{O}$ hydrogen bonds in transition metal alkoxide chemistry.

The observed linear relationship between $\Delta H^{\circ}$ and $\Delta S^{\circ}$ which we find for the first time with late transition metal alkoxides allows us to make confident predictions regarding $K_{\text {ass }}$ of such complexes with alcohols. For example, if we take $\mathrm{O}-\mathrm{H} \cdots \mathrm{O}$ hydrogen bonds of phenol with a given $\Delta H^{\circ}$ of $-20 \mathrm{~kJ} \mathrm{~mol}^{-1}$, these will produce expected $\Delta S^{\circ}$ values varying from $-56 \mathrm{~J}$ $\mathrm{K}^{-1} \mathrm{~mol}^{-1}$ with aldehydes ${ }^{26}$ to $-26 \mathrm{~J} \mathrm{~K}^{-1} \mathrm{~mol}^{-1}$ with late transition metal alkoxides. This means that the equilibrium constants $(298 \mathrm{~K})$ will differ markedly for these systems, all due to the entropy effect; the calculated equilibrium constants $\left(K_{\text {ass }}\right)$ for phenol with aldehydes or late transition metal alkoxides are 3.8 and 140.5, respectively (all $K_{\text {ass }}$ values expressed in L $\mathrm{mol}^{-1}$ ). Thus, adduct formation of transition metal alkoxides with alcohols is controlled by the entropy term, and it is this term which also controls adduct formation for several organic systems. ${ }^{110}$

Solution Behavior of Alcohol Adducts: Exchange of the Alkoxide Group between the Alkoxide Ligand and HydrogenBonded Alcohol. The $\mathrm{O}-\mathrm{H} \cdots \mathrm{O}$ hydrogen-bonded adducts 5-10 show two sets of ${ }^{1} \mathrm{H}$ NMR resonances corresponding to the alkoxide or (substituted) phenoxide unit $(\mathrm{Pd}-\mathrm{OR})$ and the associated alcohol or (substituted) phenol (ROH). This observation means that alkoxide-alcohol exchange is slow on the NMR time scale. However, phenoxide-phenol exchange is fast on the laboratory time scale; the 1:1 addition of perdeuteriophenol $\left(\mathrm{C}_{6} \mathrm{D}_{5} \mathrm{OD}\right)$ to a $\mathrm{CDCl}_{3}$ solution of the phenoxide complex 3

(26) The relation obtained for $\mathrm{O}-\mathrm{H} \cdots \mathrm{O}$ hydrogen bonding of phenol to aldehydes is $\Delta S^{\circ}=3.10 \Delta H^{\circ}+6.0$ ( $\Delta H^{\circ}$ in $\mathrm{kJ} \mathrm{mol}^{-1}$; nine data points): Murthy, A. S. N.; Rao, C. N. R. Appl. Spectrosc. Rev. 1968, $2,69$.

(27) de Graaf, W.; Boersma, J.; Grove, D. M.; Spek, A. L.; van Koten, G. Recl. Trav. Chim. Pays-Bas 1988, 107, 299. 
Table 3. Overview of Thermodynamic Parameters for Association of Alcohols with Late Transition Metal Alkoxide or Aryloxide Complexes ${ }^{a}$

\begin{tabular}{|c|c|c|c|c|c|}
\hline entry & compound & $\mathrm{R}$ in $\mathrm{HOR}$ & solvent & $\Delta H^{\circ}\left(\mathrm{kJ} \mathrm{mol}^{-1}\right)$ & ref \\
\hline \multicolumn{6}{|c|}{$\begin{array}{l}\text { Palladium(II) Alkoxides and Aryloxides } \\
\end{array}$} \\
\hline 1 & {$\left[\mathrm{Pd}(\mathrm{Me})\left(\mathrm{OCH}\left(\mathrm{CF}_{3}\right)_{2}\right)(\mathrm{tmeda})\right], \mathbf{1}$} & $\mathrm{CH}\left(\mathrm{CF}_{3}\right)_{2}$ & $\mathrm{CDCl}_{3}$ & -34.7 & this work \\
\hline 2 & {$\left[\mathrm{Pd}(\mathrm{Me})\left(\mathrm{OC}_{6} \mathrm{H}_{5}\right)(\mathrm{tmeda})\right], \mathbf{3}$} & $\mathrm{C}_{6} \mathrm{H}_{5}$ & $\mathrm{CDCl}_{3}$ & -29.1 & this work \\
\hline 3 & trans $-\left[\mathrm{Pd}(\mathrm{Me})\left(\mathrm{OC}_{6} \mathrm{H}_{5}\right)\left(\mathrm{PMe}_{3}\right)_{2}\right]$ & $\mathrm{C}_{6} \mathrm{H}_{5}$ & $\mathrm{CD}_{2} \mathrm{Cl}_{2}$ & -23.5 & $10 \mathrm{a}$ \\
\hline 4 & trans $-\left[\mathrm{Pd}\left(\mathrm{OC}_{6} \mathrm{H}_{5}\right)_{2}(\text { pyrrolidine })_{2}\right]$ & $\mathrm{C}_{6} \mathrm{H}_{5}$ & $\mathrm{CDCl}_{3}$ & -22.6 & 13 \\
\hline 5 & trans- $\left[\mathrm{Pd}\left(\mathrm{OC}_{6} \mathrm{H}_{5}\right)_{2}(\text { pyrrolidine-Me })_{2}\right]$ & $\mathrm{C}_{6} \mathrm{H}_{5}$ & $\mathrm{CDCl}_{3}$ & -22.2 & 13 \\
\hline 6 & {$\left[\mathrm{Pd}(\mathrm{Me})\left(\mathrm{OC}_{6} \mathrm{H}_{5}\right)(\mathrm{dmpe})\right]$} & $\mathrm{C}_{6} \mathrm{H}_{5}$ & $\mathrm{CD}_{2} \mathrm{Cl}_{2}$ & -17.1 & $10 \mathrm{a}$ \\
\hline \multicolumn{6}{|c|}{ Other Transition Metal Alkoxides and Aryloxides } \\
\hline 7 & {$\left[\mathrm{Rh}\left(\mathrm{OC}_{6} \mathrm{H}_{4}-4-\mathrm{Me}\right)\left(\mathrm{PMe}_{3}\right)_{3}\right]$} & $\mathrm{C}_{6} \mathrm{H}_{4}-4-\mathrm{Me}$ & hexane & -58.6 & $10 \mathrm{~b}$ \\
\hline 8 & {$\left[\mathrm{Rh}\left(\mathrm{OC}_{6} \mathrm{H}_{4}-4-\mathrm{Me}\right)\left(\mathrm{PMe}_{3}\right)_{3}\right]$} & $\mathrm{C}_{6} \mathrm{H}_{4}-4-\mathrm{Me}$ & benzene & -47.9 & $10 \mathrm{~b}$ \\
\hline 9 & $c i s-\left[\mathrm{Pt}(\mathrm{Me})\left(\mathrm{OCH}\left(\mathrm{CF}_{3}\right)_{2}\right)\left(\mathrm{PMe}_{3}\right)_{2}\right]$ & $\mathrm{CH}\left(\mathrm{CF}_{3}\right)_{2}$ & toluene & -24.7 & $10 \mathrm{f}$ \\
\hline 10 & $c i s-\left[\mathrm{Pt}(\mathrm{Me})\left(\mathrm{OCH}\left(\mathrm{CF}_{3}\right)_{2}\right)\left(\mathrm{PMe}_{3}\right)_{2}\right]$ & $\mathrm{CH}\left(\mathrm{CF}_{3}\right)_{2}$ & $\mathrm{CD}_{2} \mathrm{Cl}_{2}$ & -21.3 & $10 \mathrm{f}$ \\
\hline
\end{tabular}

${ }^{a}$ In the case of a deuterated solvent the Scatchard method was applied; calorimetry was used when nondeuterated solvents were used.

immediately results in the appearance of signals for (associated) phenol and reduction of the phenoxide ligand signals to half their original intensity.

The ${ }^{1} \mathrm{H}$ NMR spectra $\left(\mathrm{C}_{6} \mathrm{D}_{5} \mathrm{CD}_{3}\right)$ of the adduct 5 at $25^{\circ} \mathrm{C}$ show well-resolved pairs of septet signals for the $\mathrm{OCH}$ hydrogens of the fluorinated alkoxide ligand and the associated fluorinated alcohol at 4.40 and $4.56 \mathrm{ppm}$, respectively. Raising the temperature $\left(25-80^{\circ} \mathrm{C}\right)$ causes a high-field shift of the septet at $4.56 \mathrm{ppm}$ toward the position of unassociated alcohol; the other septet (from the alkoxide unit) remains at the same resonance position. Surprisingly, Kim et al. found for [Pd(Me)$\left.\left(\mathrm{OCH}\left(\mathrm{CF}_{3}\right)(\mathrm{Ph})\right)\left(\mathrm{PMe}_{3}\right)_{2}\right] \cdot \mathrm{HOCH}\left(\mathrm{CF}_{3}\right)(\mathrm{Ph})$ (an adduct with phosphine ligands that bears analogy to the tmeda adduct 5) that there is intramolecular alkoxide-alcohol exchange with $\mathrm{OCH}$ hydrogens of the alkoxide and alcohol coalescing at 0 ${ }^{\circ} \mathrm{C} .{ }^{10 a}$ The same exchange process was proposed earlier in a study of rhodium(I) aryloxide complexes having associated phenol. ${ }^{10 \mathrm{~b}}$ In our system the alkoxide-alcohol exchange process is not observed directly due to a shift of the association equilibrium at higher temperatures toward unassociated palladium alkoxide complex and free alcohol (eq 1) as explained below. Therefore, in order to determine thermodynamic parameters for the intramolecular alkoxide-alcohol exchange for complex 5 (eq 8), spin saturation transfer (sst) experiments

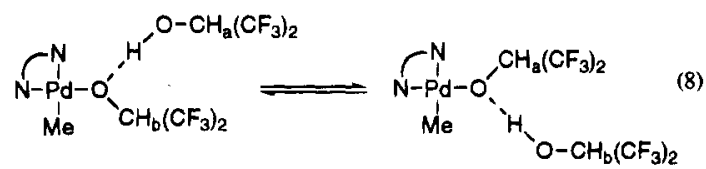

using the Forsén-Hoffman method ${ }^{28}$ were performed at low temperature. The rate constants $(k)$ and lattice relaxation times for the alkoxide $\mathrm{OCH}$ hydrogen $\left(T_{\mathrm{b}}\right)$ and associated alcohol OCH hydrogen $\left(T_{\mathrm{a}}\right)$ were determined at four different temperatures in the range $254-298 \mathrm{~K}$ (see the Experimental Section), Changing the concentration of complex $\mathbf{5}$ does not influence the rate constant $(k)$ for the exchange process, indicating that it indeed proceeds mainly by an intramolecular mechanism. On the basis of the Arrhenius equation the relationship between $\ln$ $k$ and $1 / T$ as derived from the ${ }^{1} \mathrm{H}$ NMR data provides the activation energy $E_{\mathrm{a}}=60.8 \pm 1.7 \mathrm{~kJ} \mathrm{~mol}^{-1}$ and the frequency factor $A=7.1 \times 10^{10} \mathrm{~s}^{-1}$. Figure 6 shows a plot of $\ln (k / T)$ versus $1 / T$ that provides through use of the Eyring equation the following thermodynamic parameters for the exchange process: $\Delta G^{\circ}=70.1 \pm 2.6 \mathrm{~kJ} \mathrm{~mol}^{-1}, \Delta H^{\circ}=58.6 \pm 2.2 \mathrm{~kJ} \mathrm{~mol}^{-1}$, and $\Delta S^{\circ}=-38.6 \pm 4.5 \mathrm{~J} \mathrm{~K}^{-1} \mathrm{~mol}^{-1}$. The Gibbs free energy for the intramolecular alkoxide-alcohol exchange in complex 5 is considerably higher than those reported for analogous phosphine-ligated palladium alkoxide complexes $\left(\Delta G^{\circ}=55-\right.$ $60 \mathrm{~kJ} \mathrm{~mol}^{-1}$ ). ${ }^{10 \mathrm{a}}$

(28) Mann, B. E. J. Magn. Reson. 1976, 21, 17 and references cited therein.

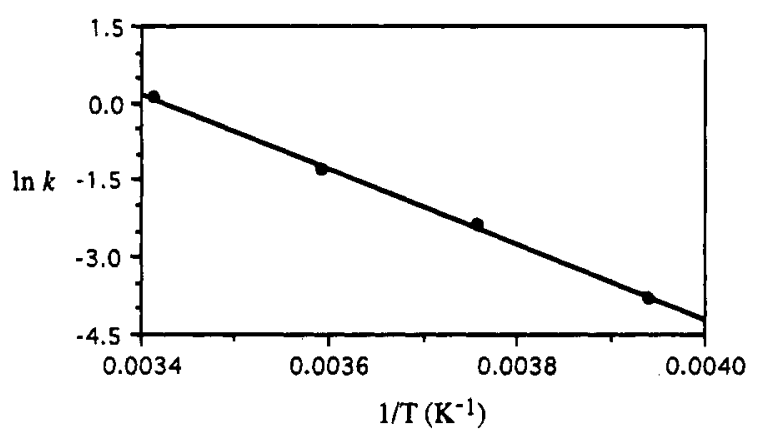

Figure 6. Eyring plot for the intramolecular alkoxide-alcohol exchange process in complex 5 .

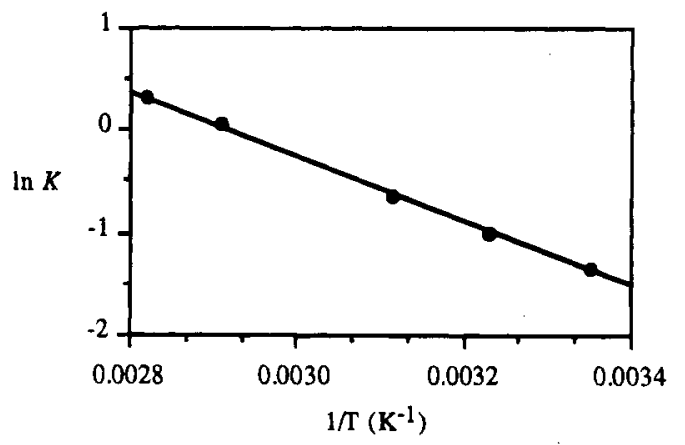

Figure 7. Van't Hoff plot for the equilibrium mixture of $\mathbf{1}$ and 3.

We have further studied exchange reactions of $\mathrm{HOCH}\left(\mathrm{CF}_{3}\right)_{2}$ with the phenoxide ligand in $\left[\mathrm{Pd}(\mathrm{Me})\left(\mathrm{OC}_{6} \mathrm{H}_{5}\right)\right.$ (tmeda)] (3). This phenoxide-alkoxide exchange leads to an equilibrium mixture of the methylpalladium complexes 1 and $\mathbf{3}$ (eq 9). The tem-

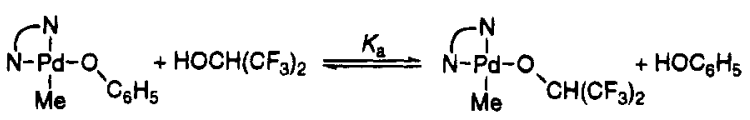

perature dependence of the equilibrium constants $K_{\mathrm{a}}$ for this reaction is shown in Figure 7, and the following thermodynamic parameters have been determined from this plot: $\Delta G^{\circ}=3.4$ $\pm 2.0 \mathrm{~kJ} \mathrm{~mol}^{-1}, \Delta H^{\circ}=26.5 \pm 1.5 \mathrm{~kJ} \mathrm{~mol}^{-1}$, and $\Delta S^{\circ}=77.4$ $\pm 4.2 \mathrm{~J} \mathrm{~K}^{-1} \mathrm{~mol}^{-1}$. Since the calculated equilibrium constant for this reaction $\left(-\log K_{\mathrm{a}}=0.7\right.$ ), based on the acidity constants of phenol $\left(\mathrm{p} K_{\mathrm{a}}=10.0\right)$ and $\mathrm{HOCH}\left(\mathrm{CF}_{3}\right)_{2}\left(\mathrm{p} K_{\mathrm{a}}=9.3\right)$, is similar to the measured $-\log K_{\mathrm{a}}$ of 0.6 , we conclude that this process is controlled by the acidity constants of the alcohols applied. For alkoxide-alcohol exchange two mechanisms are proposed in the literature: a dissociative pathway (A) and an associative pathway (B) (see Figure 8). The rate-limiting step in the dissociative pathway is the ionization of $\mathrm{RO}^{-}$from the palladium alkoxide complex if one assumes that recoordination of the alkoxide anion to the palladium center is fast. ${ }^{21}$ Kinetic studies concerning platinum methoxide complexes have shown that 

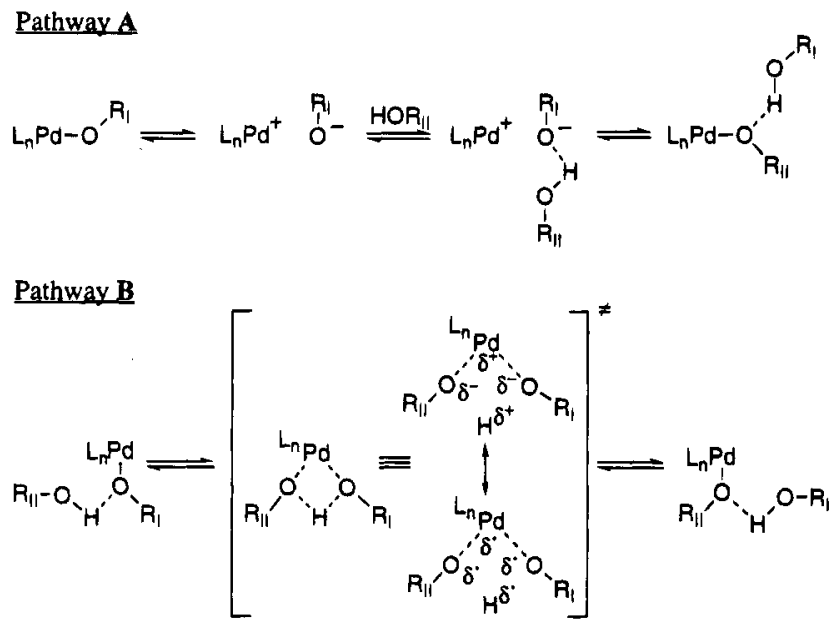

Figure 8. Mechanisms for the alkoxide-alcohol exchange process.

there is an upper limit for the rate of methoxide dissociation ( $r$ $=10^{-7} \mathrm{~s}^{-1} ; \Delta G^{\circ}>110 \mathrm{~kJ} \mathrm{~mol}^{-1}$ ), and this means that the exchange process probably does not proceed by alkoxide dissociation for late transition metal alkoxides. ${ }^{1 c}$ Mechanistic studies concerning these thermoneutral exchange reactions have shown them to exhibit bimolecular kinetics over a wide rangeof conditions, and it has been concluded that exchange of alcohol and alkoxide is likely to involve an associative pathway for late transition metal alkoxides (pathway B; see Figure 8). ${ }^{1 c, 21}$ Other evidence pointing to the involvement of an associative pathway is the fact that at low alcohol concentrations donor molecules can compete with the alcohol for the necessary open coordination site on the metal, thereby retarding the exchange process. ${ }^{1 \mathrm{c}}$ An associative mechanism involves the formation of a fivecoordinate transition state in the exchange process, and recently it has been suggested that this transition state (see Figure 8) has both hydrogen atom transfer and proton transfer character. ${ }^{21}$ The ability of the methylpalladium alkoxide complexes $1-4$ to form strong $\mathrm{O}-\mathrm{H} \cdots \mathrm{O}$ hydrogen bonds to alcohols probably assists the formation of a five-coordinate species by holding the oxygen atom of the associated alcohol in the first coordination sphere of the metal center.

Concluding Remarks. The results presented in this paper serve to illustrate that chelating $\mathrm{N}$-donor ligands are perfectly suitable for stabilizing organometallic palladium(II) species with alkoxide or aryloxide ligands. The ready accessibility and thermal stability of the complexes prepared emphasize a view that "unconventional" combinations of soft metal centers (e.g., $\mathrm{Pd}$ (II) and hard ligands (e.g., - OR) are achievable with appropriate supporting ligand arrays. Although further studies are required to investigate the potential of these complexes in synthetic and catalytic processes, it is already clear that the tendency of such complexes to form adducts with alcohols is an important characteristic. Our thermodynamic data show $\mathrm{O}-\mathrm{H} \cdots \mathrm{O}$ hydrogen bonds to be strong, and the linear relationship between $\Delta H^{\circ}$ and $\Delta S^{\circ}$ for adduct formation, which has parallels with organic systems, is a predictive tool that will be useful in understanding reactions of $\mathrm{Pd}-\mathrm{OR}$ species with many organic compounds.

\section{Experimental Section}

General Considerations. Reactions were performed in an atmosphere of nitrogen using standard Schlenk techniques. $\mathrm{C}_{6} \mathrm{H}_{6}, \mathrm{Et}_{2} \mathrm{O}$, and pentane were freshly distilled from sodium benzophenone-ketyl. $\mathrm{CH}_{2}$ $\mathrm{Cl}_{2}$ was distilled from $\mathrm{CaH}_{2}$. All other solvents were used as received. The solvents acetone ( $\mathrm{pa})$, methanol (pa), and acetonitrile (pa) and the materials 1,1,1,3,3,3-hexafluoro-2-propanol, 2,2'-bipyridyl (bpy), phenol, $p$-nitrophenol, 2,4-dimethylphenol, catechol, and Celite (filter aid) were purchased from Janssen Chimica. The complexes $\left[\mathrm{Pd}(\mathrm{Me})_{2-}\right.$ (tmeda) $],{ }^{17 a, 27}\left[\mathrm{Pd}(\mathrm{Me})_{2}(\mathrm{bpy})\right],{ }^{17 a, 29}$ and $[\mathrm{Pd}(\mathrm{Me})(\mathrm{MeCN})(\mathrm{bpy})] \mathrm{BF}_{4}{ }^{30}$ were prepared according to the literature. Sodium 1,1,1,3,3,3-hexafluoro2-propoxide was prepared from 1,1,1,3,3,3-hexafluoro-2-propanol and $\mathrm{NaH}$ in THF. ${ }^{1} \mathrm{H}(300.13 \mathrm{MHz})$ and ${ }^{13} \mathrm{C}$ NMR $(75.03 \mathrm{MHz})$ spectra were recorded on a Bruker $\mathrm{AC} 300$ spectrometer at ambient temperature in deuterated solvents $\left(\mathrm{CDCl}_{3}, \mathrm{C}_{6} \mathrm{D}_{6}\right.$, and acetone- $\left.d_{6}\right)$ obtained from ISOTEC Inc. Elemental analyses were carried out by Dornis und Kolbe, Mikroanalytisches Laboratorium, Mülheim a.d. Ruhr, Germany.

Synthesis of Methylpalladium(II) Alkoxides and Aryloxides and Their Adducts. Method A from Dimethylpalladium(II) Complexes. Preparation of $\left[\mathbf{P d}(\mathbf{M e})\left(\mathbf{O C H}\left(\mathbf{C F}_{3}\right)_{2}\right)\right.$ (tmeda)] (1). 1,1,1,3,3,3Hexafluoro-2-propanol $(0.56 \mathrm{~mL}, 5.3 \mathrm{mmol})$ was added dropwise to a solution of $\left[\mathrm{Pd}(\mathrm{Me})_{2}\right.$ (tmeda) $(1.34 \mathrm{~g}, 5.3 \mathrm{mmol})$ in $\mathrm{Et}_{2} \mathrm{O}(10 \mathrm{~mL})$. The resulting yellow solution was stirred for $1 \mathrm{~h}$, after which the solution was evaporated to dryness under reduced pressure. The yellow residue was washed twice with pentane $(2 \times 5 \mathrm{~mL})$ and dried in vacuo. The residue was redissolved in $\mathrm{Et}_{2} \mathrm{O}(10 \mathrm{~mL})$ and filtered over Celite. The filtrate was evaporated to a small volume (ca. $3 \mathrm{~mL}$ ), and the pure product 1 was obtained by slow diffusion of pentane into the $\mathrm{Et}_{2} \mathrm{O}$ solution. The resulting yellow crystals were washed with pentane $(2$ $\times 5 \mathrm{~mL}$ ) and dried in vacuo. Yield: $2.01 \mathrm{~g}(94 \%)$. Mp: $127^{\circ} \mathrm{C}$ dec. ${ }^{1} \mathrm{H}$ NMR $\left(\mathrm{CDCl}_{3}\right): \delta 4.00$ (septet, $\left.1 \mathrm{H},{ }^{3} J_{\mathrm{H} . \mathrm{F}}=7 \mathrm{~Hz}, \mathrm{OCH}\right), 2.63-$ $2.44\left(\mathrm{~m}, 4 \mathrm{H}, \mathrm{CH}_{2} \mathrm{CH}_{2}\right), 2.55\left(\mathrm{~s}, 6 \mathrm{H}, \mathrm{N}\left(\mathrm{CH}_{3}\right)_{2}\right), 2.47\left(\mathrm{~s}, 6 \mathrm{H}, \mathrm{N}\left(\mathrm{CH}_{3}\right)_{2}\right)$, $0.21\left(\mathrm{~s}, 3 \mathrm{H}, \mathrm{PdCH}_{3}\right),{ }^{13} \mathrm{C} \mathrm{NMR}\left(\mathrm{CDCl}_{3}\right): \delta 123.80\left(\mathrm{q},{ }^{1} J_{\mathrm{C}, \mathrm{F}}=290\right.$ $\left.\mathrm{Hz}, \mathrm{CF}_{3}\right), 75.08$ (septet, $\left.{ }^{2} J_{\mathrm{C}, \mathrm{F}}=30 \mathrm{~Hz}, \mathrm{OCH}\right), 63.29\left(\mathrm{NCH}_{2}\right), 57.41$ $\left(\mathrm{NCH}_{2}\right), 51.06\left(\mathrm{NCH}_{3}\right), 46.80\left(\mathrm{NCH}_{3}\right),-0.71\left(\mathrm{PdCH}_{3}\right)$. Anal. Calcd for $\mathrm{C}_{10} \mathrm{H}_{20} \mathrm{~F}_{6} \mathrm{~N}_{2} \mathrm{OPd}$ : C, 29.68; $\mathrm{H}, 4.98 ; \mathrm{N}, 6.92$. Found: $\mathrm{C}, 29.86 ; \mathrm{H}$, $4.98 ; \mathrm{N}, 6.87$.

Preparation of $\left[\mathrm{Pd}(\mathrm{Me})\left(\mathrm{OCH}\left(\mathrm{CF}_{3}\right)_{2}\right)(\mathrm{bpy})\right](2)$. To a suspension of $\left[\mathrm{Pd}(\mathrm{Me})_{2}(\mathrm{bpy})\right](0.50 \mathrm{~g}, 1.7 \mathrm{mmol})$ in $\mathrm{C}_{6} \mathrm{H}_{6}(10 \mathrm{~mL})$ was added 1,1,1,3,3,3-hexafluoro-2-propanol $(0.18 \mathrm{~mL}, 1.7 \mathrm{mmol})$. The suspension turned gradually into a yellow solution which was filtered over Celite after $1 \mathrm{~h}$. The solvent was evaporated from the filtrate, and the resulting yellow solid was washed with pentane $(2 \times 5 \mathrm{~mL})$ and dried in vacuo. This afforded 2 as a pale yellow solid. Yield: $0.61 \mathrm{~g}(81 \%)$. Mp: $176{ }^{\circ} \mathrm{C}$ dec. ${ }^{1} \mathrm{H} \mathrm{NMR}\left(\mathrm{CDCl}_{3}\right): \delta 8.94\left(\mathrm{~d}, 1 \mathrm{H},{ }^{3} J_{\mathrm{H}, \mathrm{H}}=7 \mathrm{~Hz}\right.$, $\left.H_{6}\right), 8.65\left(\mathrm{~d}, 1 \mathrm{H},{ }^{3} J_{\mathrm{H}, \mathrm{H}}=7 \mathrm{~Hz}, H_{6}^{\prime}\right), 8.04-7.99\left(\mathrm{~m}, 4 \mathrm{H}, H_{3}, H_{3}^{\prime}, H_{4}\right.$, $\left.H_{4}^{\prime}\right), 7.59\left(\mathrm{td}, 1 \mathrm{H},{ }^{3} J_{\mathrm{H} . \mathrm{H}}=7 \mathrm{~Hz},{ }^{4} J_{\mathrm{H} . \mathrm{H}}=1 \mathrm{~Hz}, H_{5}\right), 7.45\left(\mathrm{td}, 1 \mathrm{H},{ }^{3} J_{\mathrm{H}, \mathrm{H}}\right.$ $\left.=7 \mathrm{~Hz},{ }^{4} J_{\mathrm{H} . \mathrm{H}}=1 \mathrm{~Hz}, H^{\prime}{ }_{5}\right), 4.34$ (septet, $\left.1 \mathrm{H},{ }^{3} J_{\mathrm{H}, \mathrm{F}}=7 \mathrm{~Hz}, \mathrm{OCH}\right), 0.83$ $\left(\mathrm{s}, 3 \mathrm{H}, \mathrm{PdCH}{ }_{3}\right) .{ }^{13} \mathrm{C} \mathrm{NMR}\left(\mathrm{CDCl}_{3}\right): \delta 157.19\left(C_{2}\right), 152.29\left(C_{2}^{\prime}\right), 150.33$ $\left(C_{6}\right), 148.05\left(C_{6}^{\prime}\right), 138.45\left(C_{5}\right), 137.96\left(C_{5}^{\prime}\right), 126.44\left(C_{4}\right), 126.13\left(C_{4}^{\prime}\right)$, $122.25\left(C_{3}\right), 120.73\left(C_{3}^{\prime}\right), 76.24$ (septet, $\left.{ }^{2} J_{C, F}=30 \mathrm{~Hz}, \mathrm{OCH}\right), 3.69$ $\left(\mathrm{PdCH}_{3}\right)$. Anal. Calcd for $\mathrm{C}_{17} \mathrm{H}_{12} \mathrm{~F}_{6} \mathrm{~N}_{2} \mathrm{OPd}$ : C, 37.82; $\mathrm{H}, 2.72 ; \mathrm{N}, 6.30$. Found: C, 37.69; $\mathrm{H}, 2.67 ; \mathrm{N}, 6.38$.

Preparation of [Pd(Me) $\left(\mathrm{OC}_{6} \mathrm{H}_{5}\right)$ (tmeda)] (3). Phenol (0.17 g, 1.8 mmol) was added to a solution of $\left[\mathrm{Pd}(\mathrm{Me})_{2}(\mathrm{tmeda})\right](0.43 \mathrm{~g}, 1.7 \mathrm{mmol})$ in $\mathrm{Et}_{2} \mathrm{O}(15 \mathrm{~mL})$. After $1 \mathrm{~h}$ the product 3 which had precipitated was isolated by decantation, washed with pentane $(2 \times 5 \mathrm{~mL})$, and dried in vacuo. Crystals suitable for a $\mathrm{X}$-ray structure determination were obtained by slow diffusion of pentane into an $\mathrm{Et}_{2} \mathrm{O}$ solution of 3 . The resulting pale yellow crystals were washed with pentane $(2 \times 5 \mathrm{~mL})$ and dried in vacuo. Yield: $0.48 \mathrm{~g}(86 \%)$. Mp: $153^{\circ} \mathrm{C}$ dec. ${ }^{1} \mathrm{H}$ NMR $\left(\mathrm{CDCl}_{3}\right): \delta 7.03(\mathrm{~m}, 4 \mathrm{H}, o, m-\mathrm{Ph}), 6.40(\mathrm{~m}, 1 \mathrm{H}, p-\mathrm{Ph}), 2.65-2.41(\mathrm{~m}$, $\left.4 \mathrm{H}, \mathrm{CH}_{2} \mathrm{CH}_{2}\right), 2.56\left(\mathrm{~s}, 6 \mathrm{H}, \mathrm{N}\left(\mathrm{CH}_{3}\right)_{2}\right), 2.44\left(\mathrm{~s}, 6 \mathrm{H}, \mathrm{N}\left(\mathrm{CH}_{3}\right)_{2}\right), 0.37$ (s, $\left.3 \mathrm{H}, \mathrm{PdCH})_{3}\right) .{ }^{13} \mathrm{C} \mathrm{NMR}\left(\mathrm{CDCl}_{3}\right): \delta 168.80$ (ipso- $\left.\mathrm{C} \mathrm{Ph}\right), 128.47(\mathrm{~m}-\mathrm{C}$ $\mathrm{Ph}), 120.33(o-C \mathrm{Ph}), 112.62(p-C \mathrm{Ph}), 63.29\left(\mathrm{NCH}_{2}\right), 57.20\left(\mathrm{NCH}_{2}\right)$, $50.91\left(\mathrm{NCH}_{3}\right), 47.62\left(\mathrm{NCH}_{3}\right),-3.47\left(\mathrm{PdCH}_{3}\right)$. Anal. Calcd for $\mathrm{C}_{13} \mathrm{H}_{24} \mathrm{~N}_{2} \mathrm{OPd}: \mathrm{C}, 47.21 ; \mathrm{H}, 7.31 ; \mathrm{N}, 8.47$. Found: $\mathrm{C}, 47.28 ; \mathrm{H}, 7.26$; N, 8.41 .

Preparation of $\left[\mathrm{Pd}(\mathrm{Me})\left(\mathrm{OC}_{6} \mathrm{H}_{4-4}-\mathrm{NO}_{2}\right)(\right.$ tmeda) $]$ (4). The preparation of this complex was carried out using the procedure described above for 3, employing $p$-nitrophenol as the reagent $(2.10 \mathrm{mmol})$ and $\left[\mathrm{Pd}(\mathrm{Me})_{2}\right.$ (tmeda) $](2.00 \mathrm{mmol})$. Crystals suitable for an X-ray structure determination were obtained by slow diffusion of pentane into an $\mathrm{Et}_{2} \mathrm{O}$ solution of 4 . The resulting orange needles were washed with pentane $(2 \times 5 \mathrm{~mL})$ and dried in vacuo. Yield: $0.61 \mathrm{~g}(82 \%)$. Mp: $172{ }^{\circ} \mathrm{C}$ dec. ${ }^{1} \mathrm{H}$ NMR (acetone- $\left.d_{6}\right): \delta 7.98\left(\mathrm{~d}, 2 \mathrm{H},{ }^{3} J_{\mathrm{H}, \mathrm{H}}=7 \mathrm{~Hz}, m-H \mathrm{Ar}\right)$, $6.87\left(\mathrm{~d},{ }^{3} J_{\mathrm{H}, \mathrm{H}}=7 \mathrm{~Hz}, o-\mathrm{H} \mathrm{Ar}\right), 2.75-2.55\left(\mathrm{~m}, 4 \mathrm{H}, \mathrm{CH}_{2} \mathrm{CH}_{2}\right), 2.70(\mathrm{~s}$, $\left.6 \mathrm{H}, \mathrm{N}\left(\mathrm{CH}_{3}\right)_{2}\right), 2.49\left(\mathrm{~s}, 6 \mathrm{H}, \mathrm{N}\left(\mathrm{CH}_{3}\right)_{2}\right), 0.43\left(\mathrm{~s}, 3 \mathrm{H}, \mathrm{PdCH}{ }_{3}\right) .{ }^{13} \mathrm{C} \mathrm{NMR}$ (acetone- $d_{6}$ ): $\delta 176.42$ (ipso- $C \mathrm{Ar}$ ), $126.41(m-C \mathrm{Ar}), 126.17$ (o-C Ar),

(29) Byers, P. K.; Canty, A. J. Organometallics 1990, 9, 210.

(30) Byers, P. K.; Skelton, B. W.; White, A. H.; Canty, A. J. J. Organomet. Chem. 1990, 393, 299. 
116.07 (p-C Ar), $63.59\left(\mathrm{NCH}_{2}\right), 57.19\left(\mathrm{NCH}_{2}\right), 51.23\left(\mathrm{NCH}_{3}\right), 47.65$ $\left(\mathrm{NCH}_{3}\right),-2.54\left(\mathrm{PdCH}_{3}\right)$. Anal. Calcd for $\mathrm{C}_{13} \mathrm{H}_{23} \mathrm{~N}_{3} \mathrm{O}_{3} \mathrm{Pd}$ : C, 41.55; H, 6.17; N, 11.18. Found: C, $41.95 ; \mathrm{H}, 6.00 ; \mathrm{N}, 10.89$.

Preparation of $\left[\mathrm{Pd}(\mathrm{Me})\left(\mathrm{OCH}\left(\mathrm{CF}_{3}\right)_{2}\right)(\right.$ tmeda $\left.)\right] \cdot \mathrm{HOCH}\left(\mathrm{CF}_{3}\right)_{2}(5)$. Complex 5 was obtained as a pale yellow solid using the procedure described for 1, employing 2 equiv of 1,1,1,3,3,3-hexafluoro-2-propanol as the reagent. Yield: $88 \%(1.8 \mathrm{mmol} \mathrm{scale}) . \mathrm{Mp}: 129^{\circ} \mathrm{C} \mathrm{dec} .{ }^{1} \mathrm{H}$ $\operatorname{NMR}\left(\mathrm{CDCl}_{3}\right): \delta 4.57$ (septet, $1 \mathrm{H},{ }^{3} J_{\mathrm{H}, \mathrm{F}}=7 \mathrm{~Hz}, \mathrm{HOCH}$ ), 4.05 (septet, $\left.1 \mathrm{H},{ }^{3} \mathrm{~J}_{\mathrm{H}, \mathrm{F}}=7 \mathrm{~Hz}, \mathrm{PdOCH}\right), 2.65-2.42\left(\mathrm{~m}, 4 \mathrm{H}, \mathrm{CH}_{2} \mathrm{CH}_{2}\right), 2.58(\mathrm{~s}, 6 \mathrm{H}$, $\left.\mathrm{N}\left(\mathrm{CH}_{3}\right)_{2}\right), 2.47\left(\mathrm{~s}, 6 \mathrm{H}, \mathrm{N}\left(\mathrm{CH}_{3}\right)_{2}\right), 0.28\left(\mathrm{~s}, 3 \mathrm{H}, \mathrm{PdCH}_{3}\right),{ }^{13} \mathrm{C}$ NMR $\left(\mathrm{C}_{6} \mathrm{D}_{6}\right): \delta 124.10\left(\mathrm{q},{ }^{1} J_{\mathrm{C}, \mathrm{F}}=290 \mathrm{~Hz}, C_{3}\right), 122.90\left(\mathrm{q},{ }^{1} J_{\mathrm{C}, \mathrm{F}}=290 \mathrm{~Hz}\right.$, $C_{F}$ ), 75.36 (septet, ${ }^{2} J_{C, F}=30 \mathrm{~Hz}, \mathrm{PdOCH}$ ), 69.28 (septet, ${ }^{2} J_{\mathrm{C}, \mathrm{F}}=30$ $\mathrm{Hz}, \mathrm{HOCH}), 62.30\left(\mathrm{NCH}_{2}\right), 56.71\left(\mathrm{NCH}_{2}\right), 50.08\left(\mathrm{NCH}_{3}\right), 46.50$ $\left(\mathrm{NCH}_{3}\right),-0.72\left(\mathrm{PdCH}_{3}\right)$. Anal. Calcd for $\mathrm{C}_{13} \mathrm{H}_{22} \mathrm{~F}_{12} \mathrm{~N}_{2} \mathrm{O}_{2} \mathrm{Pd}$ : C, 27.26; $\mathrm{H}, 3.87 ; \mathrm{N}, 4.89$. Found: C, 27.33; H, 3.95; N, 4.97.

Preparation of $\left[\mathrm{Pd}(\mathrm{Me})\left(\mathrm{OCH}\left(\mathrm{CF}_{3}\right)_{2}\right)(\mathrm{bpy})\right] \cdot \mathrm{HOCH}\left(\mathrm{CF}_{3}\right)_{2}$ (6). Complex 6 was obtained as a yellow solid using the procedure described for 2, employing 2 equiv of 1,1,1,3,3,3-hexafluoro-2-propanol as the reagent. Yield: $79 \%$ (1.5 mmol scale). Mp: $175^{\circ} \mathrm{C} \mathrm{dec} .{ }^{1} \mathrm{H}$ NMR $\left(\mathrm{CDCl}_{3}\right): \delta 8.84\left(\mathrm{~d}, 1 \mathrm{H},{ }^{3} J_{\mathrm{H}, \mathrm{H}}=7 \mathrm{~Hz}, H_{6}\right), 8.61\left(\mathrm{~d}, 1 \mathrm{H},{ }^{3} J_{\mathrm{H}, \mathrm{H}}=7 \mathrm{~Hz}\right.$, $\left.H_{6}^{\prime}\right), 8.06-7.98\left(\mathrm{~m}, 4 \mathrm{H}, H_{3}, H^{\prime}{ }_{3}, H_{4}, H^{\prime}{ }_{4}\right), 7.58\left(\mathrm{td}, 1 \mathrm{H},{ }^{3} J_{\mathrm{H}, \mathrm{H}}=7 \mathrm{~Hz}\right.$, $\left.{ }^{4} J_{\mathrm{H}, \mathrm{H}}=1 \mathrm{~Hz}, H_{5}\right), 7.47\left(\mathrm{td}, 1 \mathrm{H},{ }^{3} J_{\mathrm{H}, \mathrm{H}}=7 \mathrm{~Hz},{ }^{4} J_{\mathrm{H}, \mathrm{H}}=1 \mathrm{~Hz}, H^{\prime \prime}{ }_{5}\right), 4.66$ (septet, $1 \mathrm{H},{ }^{3} J_{\mathrm{H}, \mathrm{F}}=7 \mathrm{~Hz}, \mathrm{HOCH}$ ), 4.34 (septet, $1 \mathrm{H},{ }^{3} J_{\mathrm{H}, \mathrm{F}}=7 \mathrm{~Hz}$, $\mathrm{PdOCH}$ ), 0.84 (s, 3H, PdCH${ }_{3}$ ). ${ }^{13} \mathrm{C}$ NMR (acetone- $d_{6}$ ): $\delta 157.92\left(\mathrm{C}_{2}\right)$, $153.73\left(C_{2}^{\prime}\right), 151.08\left(C_{6}\right), 147.74\left(C_{6}^{\prime}\right), 140.22\left(C_{5}\right), 139.74\left(C_{5}^{\prime}\right), 127.68$ $\left(C_{4}\right), 127.25\left(C_{4}^{\prime}\right), 124.27\left(C_{3}\right), 122.83\left(C_{3}^{\prime}\right), 76.90$ (septet, ${ }^{2} J_{C, F}=30$ $\mathrm{Hz}, \mathrm{PdOCH}), 69.34$ (septet, $\left.{ }^{2} J_{\mathrm{C} . \mathrm{F}}=30 \mathrm{~Hz}, \mathrm{HOCH}\right), 3.55\left(\mathrm{PdCH}_{3}\right)$. Anal. Calcd for $\mathrm{C}_{17} \mathrm{H}_{14} \mathrm{~F}_{12} \mathrm{~N}_{2} \mathrm{O}_{2} \mathrm{Pd}: \mathrm{C}, 33.33 ; \mathrm{H}, 2.30 ; \mathrm{N}, 4.57$ Found: $\mathrm{C}, 33.30 ; \mathrm{H}, 2.39 ; \mathrm{N}, 4.61$.

Preparation of $\left[\mathrm{Pd}(\mathrm{Me})\left(\mathrm{OC}_{6} \mathrm{H}_{5}\right)(\right.$ tmeda $\left.)\right] \cdot \mathrm{HOC}_{6} \mathrm{H}_{5}(7)$. Complex 7 was obtained as a yellow solid using the procedure described for 3 , employing 2 equiv of phenol as the reagent. Crystals of 7 (suitable for an X-ray structure determination) were obtained by slow diffusion of pentane into an $\mathrm{Et}_{2} \mathrm{O}$ solution. The resulting yellow needles were washed with pentane $(2 \times 5 \mathrm{~mL})$ and dried in vacuo. Yield: $92 \%$ (1.8 mmol scale). Mp: $154{ }^{\circ} \mathrm{C}$ dec. ${ }^{1} \mathrm{H}$ NMR $\left(\mathrm{CDCl}_{3}\right): \delta 9.1$ (br s, $1 \mathrm{H}, \mathrm{OH}), 7.23-7.03(\mathrm{~m}, 8 \mathrm{H}, o, m-H$ of PdOPh and HOPh), $6.84(\mathrm{t}$, $\left.1 \mathrm{H},{ }^{3} J_{\mathrm{H} . \mathrm{H}}=7 \mathrm{~Hz}, p-H \mathrm{HOPh}\right), 6.49\left(\mathrm{t}, 1 \mathrm{H},{ }^{3} J_{\mathrm{H} . \mathrm{H}}=7 \mathrm{~Hz}, p-H \mathrm{PdOPh}\right)$ 2.72-2.46 (m, $\left.4 \mathrm{H}, \mathrm{CH}_{2} \mathrm{CH}_{2}\right), 2.66\left(\mathrm{~s}, 6 \mathrm{H}, \mathrm{N}\left(\mathrm{CH}_{3}\right)_{2}\right), 2.50(\mathrm{~s}, 6 \mathrm{H}$, $\left.\mathrm{N}\left(\mathrm{CH}_{3}\right)_{2}\right), 0.45\left(\mathrm{~s}, 3 \mathrm{H}, \mathrm{PdCH}_{3}\right) .{ }^{13} \mathrm{C} \mathrm{NMR}\left(\mathrm{CDCl}_{3}\right): \delta 167.38$ (ipso- $\mathrm{C}$ PdOPh), 158.18 (ipso- $C \mathrm{HOPh}$ ), 129.22 (m-C PdOPh), 128.58 (m-C HOPh), 120.21 (o-C PdOPh), 118.56 ( $p-C \mathrm{HOPh}), 116.24$ (o-C HOPh), $113.70(p-C \mathrm{PdOPh}), 63.36\left(\mathrm{NCH}_{2}\right), 57.26\left(\mathrm{NCH}_{2}\right), 51.02\left(\mathrm{NCH}_{3}\right)$, $47.65\left(\mathrm{NCH}_{3}\right),-2.76\left(\mathrm{PdCH}_{3}\right)$. Anal. Calcd for $\mathrm{C}_{19} \mathrm{H}_{30} \mathrm{~N}_{2} \mathrm{O}_{2} \mathrm{Pd}: \mathrm{C}$, $53.71 ; \mathrm{H}, 7.12 ; \mathrm{N}, 6.59$. Found: C, 53.77; H, 7.19; N, 6.65.

Preparation of [Pd(Me) $\left(\mathrm{OC}_{6} \mathrm{H}_{4}-4-\mathrm{NO}_{2}\right)($ tmeda $\left.)\right] \cdot \mathrm{HOC}_{6} \mathrm{H}_{4}-4-\mathrm{NO}_{2}$ (8). Complex 8 was obtained as a yellow solid using the procedure described for 2 , employing 2 equiv of $p$-nitrophenol as the reagent. Crystals of 8 (suitable for an X-ray structure determination) were obtained by slow diffusion of pentane into an $\mathrm{Et}_{2} \mathrm{O}$ solution. The resulting orange crystals were washed with pentane $(2 \times 5 \mathrm{~mL})$ and dried in vacuo. Yield: $79 \%(1.7 \mathrm{mmol} \mathrm{scale}) . \mathrm{Mp}: 170^{\circ} \mathrm{C}$. ${ }^{1} \mathrm{H}$ NMR (acetone- $\left.d_{6}\right): \delta 8.17\left(\mathrm{~d}, 2 \mathrm{H},{ }^{3} \mathrm{~J}_{\mathrm{H}, \mathrm{H}}=7 \mathrm{~Hz}, m-H \mathrm{HOAr}\right.$ ), $7.93(\mathrm{~d}, 2 \mathrm{H}$, $\left.{ }^{3} J_{\mathrm{H}, \mathrm{H}}=7 \mathrm{~Hz}, m-H \mathrm{PdOAr}\right), 7.05\left(\mathrm{~d}, 2 \mathrm{H},{ }^{3} J_{\mathrm{H} . \mathrm{H}}=7 \mathrm{~Hz}, o-H \mathrm{HOAr}\right)$, $6.89\left(\mathrm{~d}, 2 \mathrm{H},{ }^{3} J_{\mathrm{H}, \mathrm{H}}=7 \mathrm{~Hz}, o-H \mathrm{PdOAr}\right), 2.84-2.87\left(\mathrm{~m}, 2 \mathrm{H}, \mathrm{CH}_{2}\right), 2.67-$ $2.64\left(\mathrm{~m}, 2 \mathrm{H}, \mathrm{CH}_{2}\right), 2.70\left(\mathrm{~s}, 6 \mathrm{H}, \mathrm{N}\left(\mathrm{CH}_{3}\right)_{2}\right), 2.46\left(\mathrm{~s}, 6 \mathrm{H}, \mathrm{N}\left(\mathrm{CH}_{3}\right)_{2}\right), 0.29$ (s, $3 \mathrm{H}, \mathrm{PdCH}_{3}$ ). Anal. Calcd for $\mathrm{C}_{19} \mathrm{H}_{28} \mathrm{~N}_{4} \mathrm{O}_{6} \mathrm{Pd}: \mathrm{C}, 44.32 ; \mathrm{H}, 5.48$; $\mathrm{N}, 10.88$. Found: $\mathrm{C}, 44.40 ; \mathrm{H}, 5.44 ; \mathrm{N}, 10.79$.

The non-alcohol-associated complexes 1-4 cannot be regenerated from the adducts $5-8$ by washing the latter complexes with $\mathrm{Et}_{2} \mathrm{O}$ or pentane. Heating the complexes $5-8$ to $40^{\circ} \mathrm{C}$ in vacuo for $24 \mathrm{~h}$ also did not lead to loss of the hydrogen-bonded alcohol molecule to produce the complexes 1-4.

Preparation of $\left[\mathrm{Pd}(\mathrm{Me})\left(\mathrm{OC}_{6} \mathrm{H}_{5}\right)(\mathrm{bpy})\right] \cdot \mathrm{HOC}_{6} \mathbf{H}_{5}(\mathbf{9})$. Phenol $(0.42$ $\mathrm{g}, 4.5 \mathrm{mmol})$ was added to a solution of [Pd(Me) $\left.)_{2}(\mathrm{bpy})\right](0.65 \mathrm{~g}, 2.6$ mmol) in $\mathrm{CH}_{2} \mathrm{Cl}_{2}$ at $0^{\circ} \mathrm{C}$. The solution turned gradually yellow, and after $1 \mathrm{~h}$ the solvent was evaporated. The resulting yellow solid was washed twice with pentane $(2 \times 5 \mathrm{~mL})$ and dried in vacuo. Yield: $0.91 \mathrm{~g}(75 \%)$. Mp: $>200{ }^{\circ} \mathrm{C}$. ${ }^{1} \mathrm{H}$ NMR $\left(\mathrm{CDCl}_{3}\right): \delta 8.20-7.00(\mathrm{~m}$, $8 \mathrm{H}$, bpy), 7.30-7.02 (m, 8H, o, $m-H$ of PdOPh and HOPh), 7.1 (br s, $1 \mathrm{H}, \mathrm{OH}), 6.83\left(\mathrm{t}, 1 \mathrm{H},{ }^{3} J_{\mathrm{H}, \mathrm{H}}=7 \mathrm{~Hz}, p-H \mathrm{HOPh}\right), 6.58\left(\mathrm{t}, 1 \mathrm{H},{ }^{3} J_{\mathrm{H}, \mathrm{H}}=\right.$ $7 \mathrm{~Hz}, p-H \mathrm{PdOPh}$ ), 0.93 (s, 3H, PdCH${ }_{3}$ ). ${ }^{13} \mathrm{C}$ NMR (acetone- $\left.d_{6}\right): \delta$ 167.50 (ipso-C PdOPh), 158.44 (ipso-C HOPh), $157.97\left(C_{2}\right), 153.81$
$\left(C_{2}^{\prime}\right), 151.02\left(C_{6}\right), 148.78\left(C_{6}^{\prime}\right), 140.26\left(C_{5}\right), 140.03\left(C_{5}^{\prime}\right), 130.19(m-C$ PdOPh), $129.17\left(m-C\right.$ HOPh), $127.81\left(C_{4}\right), 127.60\left(C_{4}^{\prime}\right), 124.28\left(C_{3}\right)$, $122.03\left(C^{\prime}{ }_{3}\right), 121.11$ (o-C PdOPh), 120.01 (o-C HOPh), 116.13 (o-C of $\mathrm{HOPh}$ and $\mathrm{PdOPh}), 0.34\left(\mathrm{PdCH}_{3}\right)$. Anal. Calcd for $\mathrm{C}_{23} \mathrm{H}_{22} \mathrm{~N}_{2} \mathrm{O}_{2}$ Pd: C, 59.43; H, 4.77; N, 6.03. Found: C, 59.31; H, 4.85; N, 6.09.

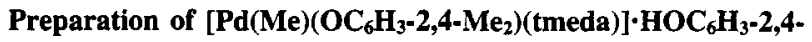
$\mathrm{Me}_{2}$ (10). Complex 10 was obtained as a yellow solid using the procedure described for 3, employing 2 equiv of 2,4-dimethylphenol as the reagent. Yield: $83 \%(1.0 \mathrm{mmol} \mathrm{scale}) . \mathrm{Mp}: 156^{\circ} \mathrm{C}$ dec. ${ }^{1} \mathrm{H}$ NMR $\left(\mathrm{C}_{6} \mathrm{D}_{6}\right): \delta 7.65\left(\mathrm{~d}, 1 \mathrm{H},{ }^{3} J_{\mathrm{H} . \mathrm{H}}=7 \mathrm{~Hz}\right), 7.11(\mathrm{~s}, 1 \mathrm{H}), 6.98(\mathrm{~d}, 1 \mathrm{H}$, $\left.{ }^{3} J_{\mathrm{H}, \mathrm{H}}=7 \mathrm{~Hz}\right), 6.86\left(\mathrm{~d}, 1 \mathrm{H},{ }^{3} J_{\mathrm{H}, \mathrm{H}}=7 \mathrm{~Hz}\right), 6.84\left(\mathrm{~d}, 1 \mathrm{H},{ }^{3} J_{\mathrm{H}, \mathrm{H}}=7 \mathrm{~Hz}\right)$, $2.70\left(\mathrm{~s}, 6 \mathrm{H}, \mathrm{N}\left(\mathrm{CH}_{3}\right)_{2}\right), 2.68$ (s, 3H, $\left.\mathrm{ArCH}_{3}\right), 2.49$ (s, 3H, $\left.\mathrm{ArCH}_{3}\right), 2.46$ (s, 6H, $\left.\mathrm{N}\left(\mathrm{CH}_{3}\right)_{2}\right), 2.30\left(\mathrm{~s}, 3 \mathrm{H}, \mathrm{ArCH}_{3}\right), 2.18\left(\mathrm{~s}, 3 \mathrm{H}, \mathrm{ArCH}_{3}\right), 1.41-$ $1.30\left(\mathrm{~m}, 4 \mathrm{H}, \mathrm{CH}_{2}\right), 0.71\left(\mathrm{~s}, 3 \mathrm{H}, \mathrm{PdCH}_{3}\right)$. Anal. Calcd for $\mathrm{C}_{23} \mathrm{H}_{38} \mathrm{~N}_{2} \mathrm{O}_{2}$ Pd: C, 57.43; H, 7.96; N, 5.82. Found: C, 57.49; H, 7.88; N, 5.80.

Preparation of $\left[\mathrm{Pd}(\mathrm{Me})\left(\mathrm{OC}_{6} \mathrm{H}_{4}-2-\mathrm{OH}\right)(\right.$ tmeda $\left.)\right](11)$. Catechol $(0.33 \mathrm{~g}, 3.0 \mathrm{mmol})$ was added to a solution of $\left[\mathrm{Pd}(\mathrm{Me})_{2}\right.$ (tmeda) $](0.70$ g, $2.8 \mathrm{mmol})$ in $\mathrm{Et}_{2} \mathrm{O}(15 \mathrm{~mL})$. After $1 \mathrm{~h}$ the product, which had precipitated as a white solid, was isolated by decantation, washed twice with pentane $(2 \times 5 \mathrm{~mL})$, and dried in vacuo. Yield: $0.87 \mathrm{~g}(90 \%)$. $\mathrm{Mp}:>200^{\circ} \mathrm{C} .{ }^{1} \mathrm{H} \mathrm{NMR}\left(\mathrm{CDCl}_{3}\right): \delta 7.16\left(\mathrm{~d}, 1 \mathrm{H},{ }^{3} J_{\mathrm{H}, \mathrm{H}}=7 \mathrm{~Hz}, \mathrm{Ar} H\right)$, $6.71\left(\mathrm{~d}, 1 \mathrm{H},{ }^{3} J_{\mathrm{H}, \mathrm{H}}=7 \mathrm{~Hz}, \operatorname{Ar} H\right), 6.70(\mathrm{br} \mathrm{s}, 1 \mathrm{H}, \mathrm{OH}), 6.63\left(\mathrm{t}, 1 \mathrm{H},{ }^{3} J_{\mathrm{H}, \mathrm{H}}\right.$ $=7 \mathrm{~Hz}, \operatorname{Ar} H), 6.38\left(\mathrm{t}, 1 \mathrm{H},{ }^{3} J_{\mathrm{H}, \mathrm{H}}=7 \mathrm{~Hz}, \operatorname{Ar} H\right), 2.70-2.40(\mathrm{~m}, 4 \mathrm{H}$, $\left.\mathrm{CH}_{2} \mathrm{CH}_{2}\right), 2.65$ (s, 6H, N( $\left.\left.\mathrm{CH}_{3}\right)_{2}\right), 2.47$ (s, 6H, N( $\left.\left.\mathrm{CH}_{3}\right)_{2}\right), 0.41$ (s, 3H, $\left.\mathrm{PdCH}_{3}\right) .{ }^{13} \mathrm{C} \mathrm{NMR}\left(\mathrm{CDCl}_{3}\right): \delta 155.23$ (ipso-C Ar), 148.66, 119.40, $118.39,113.62,111.07,63.41\left(\mathrm{NCH}_{2}\right), 57.21\left(\mathrm{NCH}_{2}\right), 51.08\left(\mathrm{NCH}_{3}\right)$, $47.54\left(\mathrm{NCH}_{3}\right),-2.95(\mathrm{PdCH})$. Anal. Calcd for $\mathrm{C}_{13} \mathrm{H}_{24} \mathrm{~N}_{2} \mathrm{O}_{2} \mathrm{Pd}: \mathrm{C}$, $45.03 ; \mathrm{H}, 6.98 ; \mathrm{N}, 8.08$. Found: $\mathrm{C}, 45.08 ; \mathrm{H}, 6.88 ; \mathrm{N}, 7.95$.

Method $B$ from Cationic Alkylpalladium(II) Complexes. Preparation of $\left[\mathrm{Pd}(\mathrm{Me})\left(\mathrm{OCH}\left(\mathrm{CF}_{3}\right)_{2}\right)(\mathrm{bpy})\right]$ (2). To a solution of $[\mathrm{Pd}(\mathrm{Me})-$ $(\mathrm{MeCN})(\mathrm{bpy})] \mathrm{BF}_{4}(0.24 \mathrm{~g}, 0.59 \mathrm{mmol})$ in acetone $(10 \mathrm{~mL})$ was added a solution of sodium 1,1,1,3,3,3-hexafluoro-2-propoxide $(0.11 \mathrm{~g}, 0.58$ $\mathrm{mmol})$ in acetone $(2 \mathrm{~mL})$. The clear solution turned immediately yellow. After $5 \mathrm{~min}$, the solution was evaporated to dryness, the yellow residue extracted with $\mathrm{CH}_{2} \mathrm{Cl}_{2}$, and the extract filtered over Celite. The yellow filtrate was evaporated to dryness, and the resulting yellow solid was washed with pentane $(2 \times 5 \mathrm{~mL})$ and dried in vacuo. This afforded the product 2 in a yield of $0.22 \mathrm{~g}(85 \%)$.

Method C. Ligand Exchange Starting from [Pd(Me)(OCH$\left.\left(\mathrm{CF}_{3}\right)_{2}\right)($ tmeda $\left.)\right](1)$. Preparation of $\left[\mathrm{Pd}(\mathrm{Me})\left(\mathrm{OCH}\left(\mathrm{CF}_{3}\right)_{2}\right)(\mathrm{bpy})\right](2)$. To a stirred solution of $\left[\mathrm{Pd}(\mathrm{Me})\left(\mathrm{OCH}\left(\mathrm{CF}_{3}\right)_{2}\right)\right.$ (tmeda)] (1) $(0.48 \mathrm{~g}, 1.2$ mmol) dissolved in a minimum of acetone $(5 \mathrm{~mL})$ was added 4 equiv of bpy $(0.75 \mathrm{~g}, 4.8 \mathrm{mmol})$. After $1 \mathrm{~h}, \mathrm{Et}_{2} \mathrm{O}$ was added, and the precipitated solid was isolated by decantation. This residue was washed with $\mathrm{Et}_{2} \mathrm{O}$ and crystallized from acetone/pentane at $-20^{\circ} \mathrm{C}$, affording yellow needles of pure 2. Yield: $0.31 \mathrm{~g}(58 \%)$.

Preparation of $\left[\mathrm{Pd}(\mathrm{Me})\left(\mathrm{OCH}\left(\mathrm{CF}_{3}\right)_{2}\right)\left(\mathrm{Ph}_{2} \mathrm{PCH}_{2} \mathrm{CH}_{2} \mathrm{NMe}_{2}\right)\right]$ (12). This complex was prepared using the procedure described for 2 (method C) employing $\mathrm{Ph}_{2} \mathrm{PCH}_{2} \mathrm{CH}_{2} \mathrm{NMe}_{2}(0.33 \mathrm{~g}, 1.3 \mathrm{mmol})$ and $[\mathrm{Pd}(\mathrm{Me})-$ $\left(\mathrm{OCH}\left(\mathrm{CF}_{3}\right)_{2}\right)$ (tmeda)] (1) $(0.48 \mathrm{~g}, 1.2 \mathrm{mmol})$. Yield: $0.59 \mathrm{~g}(91 \%)$. ${ }^{1} \mathrm{H}$ NMR (acetone- $\left.d_{6}\right): \delta 7.79-7.63(\mathrm{~m}, 4 \mathrm{H}, \mathrm{Ar}), 7.60-7.48(\mathrm{~m}, 6 \mathrm{H}$, Ar), 4.48 (septet, $\left.1 \mathrm{H},{ }^{3} J_{\mathrm{HF}}=6.5 \mathrm{~Hz}, \mathrm{OCH}\right), 2.75-2.50(\mathrm{~m}, 4 \mathrm{H}$, $\mathrm{CH}_{2} \mathrm{CH}_{2}$ ), 2.60 (s, $\left.6 \mathrm{H}, \mathrm{NCH}_{3}\right), 0.15\left(\mathrm{~d}, 3 \mathrm{H},{ }^{3} \mathrm{~J}_{\mathrm{HP}}=1.2 \mathrm{~Hz}, \mathrm{PdCH}_{3}\right.$ ). ${ }^{13} \mathrm{C}$ NMR (acetone- $\left.d_{6}\right): \delta 134.09\left(\mathrm{~d},{ }^{2} J_{\mathrm{CP}}=12 \mathrm{~Hz}, m-C\right.$ Ar), 132.02 (p-C Ar), $131.42\left(\mathrm{~d},{ }^{1} J_{\mathrm{CP}}=50 \mathrm{~Hz}\right.$, ipso-C Ar), $129.80\left(\mathrm{~d},{ }^{3} J_{\mathrm{CP}}=11\right.$ $\mathrm{Hz}, o-C \mathrm{Ar}$ ), $125.62\left(\mathrm{q},{ }^{1} J_{\mathrm{CF}}=286 \mathrm{~Hz}, C \mathrm{~F}_{3}\right), 74.98$ (septet, ${ }^{2} J_{\mathrm{CF}}=29$ $\mathrm{Hz}, \mathrm{OCH}), 59.34\left(\mathrm{~d},{ }^{2} J_{\mathrm{CP}}=5 \mathrm{~Hz}, \mathrm{NCH}_{2}\right), 47.48\left(\mathrm{NCH}_{3}\right), 31.35(\mathrm{~d}$, $\left.{ }^{1} J_{\mathrm{CP}}=12 \mathrm{~Hz}, \mathrm{PCH}\right),-3.24\left(\mathrm{~d},{ }^{2} J_{\mathrm{CP}}=7.5 \mathrm{~Hz}\right)$. Anal. Calcd for $\mathrm{C}_{20} \mathrm{H}_{24} \mathrm{~F}_{6} \mathrm{ONPPd}: \mathrm{C}, 44.01 ; \mathrm{H}, 4.43 ; \mathrm{N}, 2.57$. Found: $\mathrm{C}, 44.16 ; \mathrm{H}$, $4.42 ; \mathrm{N}, 2.67$

Preparation of $\left[\mathrm{Pd}(\mathrm{Me})\left(\mathrm{OCH}\left(\mathrm{CF}_{3}\right)_{2}\right)(\mathrm{dppe})\right]$ (13). This complex was prepared using the procedure described for 2 (method $C$ ) employing dppe $(0.13 \mathrm{~g}, 0.32 \mathrm{mmol})$ and $\left[\mathrm{Pd}(\mathrm{Me})\left(\mathrm{OCH}\left(\mathrm{CF}_{3}\right)_{2}\right)\right.$ (tmeda)] (1) $(0.11$ $\mathrm{g}, 0.29 \mathrm{mmol})$. Yield: $0.16 \mathrm{~g}(85 \%)$. NMR data: similar to those reported. ${ }^{10 a}$

Preparation of trans-[Pd(Me)(OCH(CF$\left.)_{2}\left(\mathrm{PMe}_{3}\right)_{2}\right](14)$. A solution of $\mathrm{PMe}_{3}$ in toluene $(0.78 \mathrm{mmol})$ was added to a solution of [Pd$\left.(\mathrm{Me})\left(\mathrm{OCH}\left(\mathrm{CF}_{3}\right)_{2}\right)(\mathrm{tmeda})\right](\mathbf{1})(0.14 \mathrm{~g}, 0.37 \mathrm{mmol})$ in toluene. After $1 \mathrm{~h}$, the solution was evaporated to dryness, and the residue was washed with pentane $(2 \times 5 \mathrm{~mL})$ and dried in vacuo. Yield: $0.13 \mathrm{~g}(78 \%)$. NMR data: similar to those reported. ${ }^{10 a}$

Association of Alcohol and Phenol with Alkoxide and Aryloxide Complexes. Synthesis of Methylpalladium(II) Alkoxides and Aryl- 


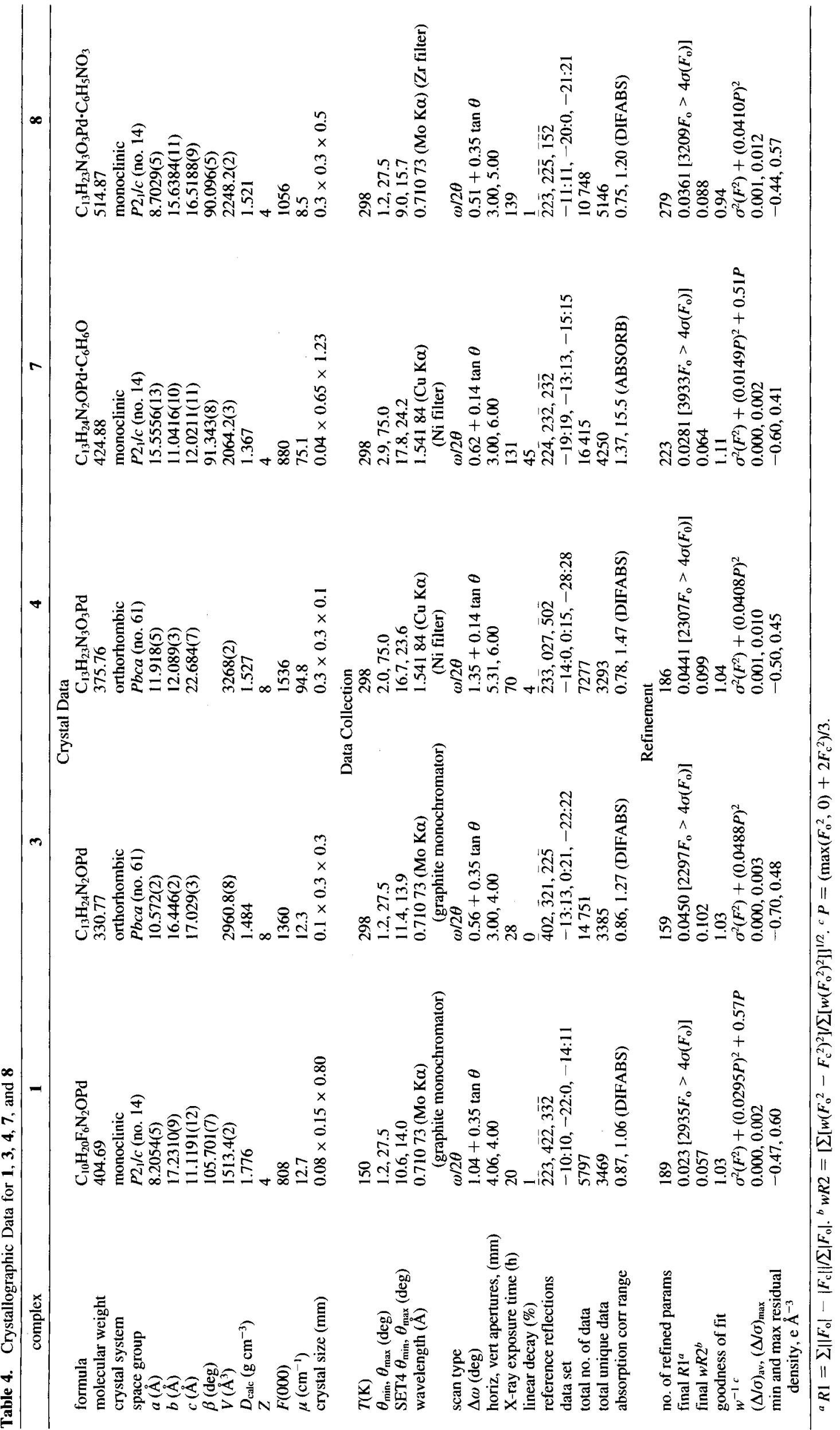


oxides. Method D. Preparation of $\left[\mathrm{Pd}(\mathrm{Me})\left(\mathrm{OCH}\left(\mathrm{CF}_{3}\right)_{2}\right)(\mathrm{tmeda})\right] \cdot$ $\mathrm{HOCH}\left(\mathrm{CF}_{3}\right)_{2}(\mathbf{5})$. To a solution of $1(0.25 \mathrm{~g}, 0.62 \mathrm{mmol})$ in $\mathrm{Et}_{2} \mathrm{O}(5$ $\mathrm{mL}$ ) was added less than 1 equiv of $1,1,1,3,3,3$-hexafluoro-2-propanol $(0.09 \mathrm{~g}, 0.54 \mathrm{mmol})$. The solution was saturated with pentane and stored at $-20{ }^{\circ} \mathrm{C}$ for $24 \mathrm{~h}$ to provide crystals of 5 . The crystals were collected by decantation, washed with pentane $(2 \times 5 \mathrm{~mL})$, and dried in vacuo. Yield: $0.31 \mathrm{~g}(88 \%)$.

Preparation of $\left[\mathrm{Pd}(\mathrm{Me})\left(\mathrm{OCH}\left(\mathrm{CF}_{3}\right)_{2}\right)(\mathrm{bpy})\right] \cdot \mathrm{HOCH}\left(\mathrm{CF}_{3}\right)_{2} \quad$ (6). This complex was prepared using the procedure described for $\mathbf{5}$ (method D) employing complex $2(0.58 \mathrm{~g}, 1.3 \mathrm{mmol})$ and 1,1,1,3,3,3-hexafluoro2-propanol $(0.13 \mathrm{~mL}, 1.2 \mathrm{mmol})$. Yield: $0.65 \mathrm{~g}(82 \%)$.

Preparation of $\left[\mathrm{Pd}(\mathrm{Me})\left(\mathrm{OC}_{6} \mathrm{H}_{5}\right)(\right.$ tmeda $\left.)\right] \cdot \mathrm{HOC}_{6} \mathrm{H}_{5}$ (7). This complex was prepared using the procedure described for $\mathbf{5}$ (method D) employing complex $1(0.20 \mathrm{~g}, 0.50 \mathrm{mmol})$ and phenol $(0.04 \mathrm{~g}, 0.45$ mmol). Yield: $0.18 \mathrm{~g}(85 \%)$.

Physical Measurements. Intramolecular Alkoxide-Alcohol Exchange. Rates, $1 / \tau$, for the two-site alkoxide $\left(H_{\mathrm{a}}\right)-$ alcohol $\left(H_{\mathrm{b}}\right)$ exchange process in the $\mathrm{O}-\mathrm{H} \cdots \mathrm{O}$ hydrogen-bonded complex $[\mathrm{Pd}(\mathrm{Me})-$ $\left(\mathrm{OCH}\left(\mathrm{CF}_{3}\right)_{2}\right.$ (tmeda) $] \cdot \mathrm{HOCH}\left(\mathrm{CF}_{3}\right)_{2}(5)$ in $\mathrm{CDCl}_{3}$ have been measured by ${ }^{1} \mathrm{H}$ NMR spin saturation transfer $(200 \mathrm{MHz}$; presaturation time, 25 $\mathrm{s}$; relaxation delay, $25 \mathrm{~s} ; 90^{\circ}$ pulse, $8 \mu \mathrm{s}$ ) using the Forsén-Hoffman method. ${ }^{28}$ Spectra were measured at four different temperatures (calibrated externally against $\mathrm{CH}_{3} \mathrm{OH}$ ). Rates were determined with use of the expression $1 / \tau=\left(1 / T_{1 \mathrm{~b}}\right)\left[\left(M_{0} / M_{\infty}\right)-1\right]$ where $T_{\mathrm{b}}$ is the spinlattice relaxation time of the proton of the coordinated $\mathrm{OCH}\left(\mathrm{CF}_{3}\right)_{2}$ unit, $M_{0}$ is the normal equilibrium magnetization, and $M_{\infty}$ is the equilibrium magnetization of proton $\mathrm{B}$ after saturating the $\mathrm{CH}$ proton resonance of site A. $T_{1 \mathrm{a}}$ and $T_{1 \mathrm{~b}}$ values have been measured by the inversionrecovery Fourier transform (IRFT) method (10 data sets, $90^{\circ}\left(180^{\circ}\right)$ pulse width of 8 (16) $\mu \mathrm{s}$, relaxation delay of $25 \mathrm{~s}, 8$ scans per data set) with the well-known sequence $\left[180^{\circ}-\tau-90^{\circ}-\text { (acquisition) }-\mathrm{T}\right]_{n}$.

Determination of Association Constants. Four NMR samples containing 1,1,1,3,3,3-hexafluoro-2-propanol or phenol at a fixed concentration $\left(0.012\right.$ or $0.010 \mathrm{M}$, respectively) in $\mathrm{CDCl}_{3}$ (dried on anhydrous $\mathrm{CaCl}_{2}$ ) with accurately weighed amounts of palladium alkoxide complex 1 or aryloxide complex 3 were prepared so as to give concentrations in the range $0.094-0.335 \mathrm{M}$. The chemical shift of the $\mathrm{OH}$ proton was measured at four different temperatures for each sample. The $\mathrm{OH}$ chemical shift of 1,1,1,3,3,3-hexafluoro-2-propanol or phenol in $\mathrm{CDCl}_{3}$ without added palladium alkoxide or aryloxide was also determined at each temperature. The microscopic association constant $k_{\text {ass }}$ is calculated at each temperature using the Scatchard equation $^{22}$ (eq 10), where $\delta(\mathrm{OH})_{\text {obs }}$ is the observed chemical shift of

$\frac{\delta(\mathrm{OH})_{\mathrm{obs}}-\delta(\mathrm{OH})_{\mathrm{alc}}}{c_{\mathrm{Pd}-\mathrm{OR}}}=-k_{\mathrm{ass}}\left\{\delta(\mathrm{OH})_{\mathrm{obs}}-\delta(\mathrm{OH})_{\mathrm{alc}}\right\}+Z$

the $\mathrm{OH}$ signal, $\delta(\mathrm{OH})_{\text {alc }}$ is the chemical shift of free, uncomplexed alcohol, $C_{\mathrm{Pd}-O R}$ is the concentration of 1 or 3 based on the weighed amount of palladium alkoxide or aryloxide complex, and $Z$ is a constant. These measurements have been done in duplicate and were found to be highly reproducible.

Structure Determination and Refinement of $1,3,4,7$, and 8 . Crystals of $1,3,4,7$, and 8 , suitable for $X$-ray diffraction, were glued onto the tip of a glass fiber and transferred to an Enraf-Nonius CAD4-T diffractometer on a rotating anode $(\mathbf{1}$ and $\mathbf{3})$ or to an Enraf-Nonius CAD4-F diffractometer with a sealed tube $(\mathbf{4}, 7$, and $\mathbf{8})$. Accurate unitcell parameters and an orientation matrix were determined by leastsquares refinement of the setting angles of 25 well-centered reflections (SET4). Reduced-cell calculations did not indicate higher lattice symmetry. ${ }^{31}$ Crystal data and details on data collection and refinement are collected in Table 4. Data were corrected for $\mathrm{L} p$ effects and for the observed linear decay of the reference reflections. An analytical

(31) Spek, A. L. J. Appl. Crystallogr. 1988, 21, 578. absorption correction, based on Gaussian integration techniques (ABSORB) ${ }^{32}$ was applied for compound 7 ; empirical absorption correction was applied for compounds $1,3,4$, and 8 (DIFABS). ${ }^{33} F_{\mathrm{c}}$ values of 1 were corrected for secondary extinction by refinement of an empirical isotropic parameter: $F_{\mathrm{c}}{ }_{\mathrm{c}}=F_{\mathrm{c}}\left[1+x F_{\mathrm{c}}{ }^{2} \lambda^{3} / \sin (2 \theta)\right]^{-1 / 4}$, with $x=2.8(3) \times 10^{-6}$. The structures were solved by automated Patterson methods and subsequent difference Fourier techniques (DIRDIR-92 $2^{34}$ for 1, 3, and 8 and SHELXS86 $6^{35}$ for 4 and 7). All structures were refined on $F^{2}$ using full-matrix least-squares techniques (SHELXL$93) ;{ }^{36}$ no observance criterion was applied during refinement. Hydrogen atoms were included in the refinement on calculated positions, riding on their carrier atoms, except for the hydroxyl hydrogen of $\mathbf{8}$, which was located on a difference Fourier map and subsequently included in the refinement. The hydroxyl hydrogen of 7 was located on a circular Fourier map around $\mathrm{O}(2)$ and refined as a rigid group allowing for rotation around the $\mathrm{C}-\mathrm{O}$ bond. All methyl hydrogen atoms were refined in a rigid group, allowing for rotation around the $\mathrm{N}-\mathrm{C}$ or $\mathrm{Pd}-\mathrm{C}$ bonds. The non-hydrogen atoms of all structures were refined with anisotropic thermal parameters. The hydrogen atoms of 1 were refined with two overall isotropic thermal parameters with values of $0.042(2)$ $\AA^{2}$ for the hydrogen atoms of the methyl groups and 0.039 (3) $\AA^{2}$ for the other hydrogen atoms. The hydrogen atoms of the other complexes were refined with a fixed isotropic thermal parameter related to the value of the equivalent isotropic thermal parameter of their carrier atoms by a factor of 1.5 for the methyl and hydroxyl hydrogen atoms and 1.2 for the other hydrogen atoms. Neutral atom scattering factors and anomalous dispersion corrections were taken from the International Tables for Crystallography. ${ }^{37}$ Geometrical calculations and illustrations were performed with PLATON; ${ }^{38}$ all calculations were performed on a DECstation 5000 cluster.

Acknowledgment. Shell Research B.V. (G.M.K.) is gratefully thanked for financial support. The work was supported in part (A.L.S.) by the Netherlands Foundation for Chemical Research (S.O.N.) with financial aid from the Netherlands Organization for Scientific Research (N.W.O.). We wish to thank Prof. Dr. A. J. Canty for critical comments.

Supporting Information Available: Tables giving further details of the structure determinations, including atomic coordinates, bond lengths and angles, and thermal parameters 1, 3, 4,7 , and 8 and ORTEP ( $30 \%$ probability level) drawings of the molecular structures of complexes 3 and 7 (29 pages); listings of observed and calculated structure factor amplitudes for $1,3,4,7$, and 8 (44 pages). This material is contained in many libraries on microfiche, immediately follows this article in the microfilm version of the journal, can be ordered from the ACS, and can be downloaded from the Internet; see any current masthead page for ordering information and Internet access instructions.

JA950876J

(32) Spek, A. L. ABSORB Program for absorption correction, Utrecht University, The Netherlands, ECM Abstract Book, 1983, p 283.

(33) Walker, N.; Stuart, D. Acta Crystallogr. 1983, A39, 158

(34) Beurskens, P. T.; Admiraal, G.; Beurskens, G.; Bosman, W. P.; García-Granda, S.; Gould, R. O.; Smits, J. M. M.; Smykalla, C. The DIRDIF program system, Technical report of the Crystallography Laboratory, University of Nijmegen, The Netherlands, 1992.

(35) Sheldrick, G. M. SHELXS86 Program for crystal structure determination, University of Göttingen, Germany, 1986.

(36) Sheldrick, G. M. SHELXL-93 Program for crystal structure refinement, University of Göttingen, Germany, 1993.

(37) Wilson, A. J. C., Ed. International Tables for Crystallography; Kluwer Academic Publishers: Dordrecht, The Netherlands, 1992; Vol. C.

(38) Spek, A. L. Acta Crystallogr. 1990, A46, C34. 